\title{
Various brain-eating amoebae: the protozoa, the pathogenesis, and the disease
}

\author{
Hongze Zhang, Xunjia Cheng (ه) \\ Department of Medical Microbiology, Key Laboratory of Medical Molecular Virology of Ministries of Education and Health, School of Basic \\ Medical Sciences, Fudan University, Shanghai 200032, China \\ (C) The Author(s) 2021. This article is published with open access at link.springer.com and journal.hep.com.cn
}

\begin{abstract}
Among various genera of free-living amoebae prevalent in nature, some members are identified as causative agents of human encephalitis, in which Naegleria fowleri followed by Acanthamoeba spp. and Balamuthia mandrillaris have been successively discovered. As the three dominant genera responsible for infections, Acanthamoeba and Balamuthia work as opportunistic pathogens of granulomatous amoebic encephalitis in immunocompetent and immunocompromised individuals, whereas Naegleria induces primary amoebic meningoencephalitis mostly in healthy children and young adults as a more violent and deadly disease. Due to the lack of typical symptoms and laboratory findings, all these amoebic encephalitic diseases are difficult to diagnose. Considering that subsequent therapies are also affected, all these brain infections cause significant mortality worldwide, with more than $90 \%$ of the cases being fatal. Along with global warming and population explosion, expanding areas of human and amoebae activity in some regions lead to increased contact, resulting in more serious infections and drawing increased public attention. In this review, we summarize the present information of these pathogenic free-living amoebae, including their phylogeny, classification, biology, and ecology. The mechanisms of pathogenesis, immunology, pathophysiology, clinical manifestations, epidemiology, diagnosis, and therapies are also discussed.
\end{abstract}

Keywords free-living amoebae; central nervous system infection; primary amoebic meningoencephalitis; granulomatous amoebic encephalitis

\section{Introduction}

As an easily neglected source of infection, free-living protists exist worldwide and potentially cause infections in humans and other animals, leading to serious clinical problems [1]. Their infection has low morbidity but is usually characterized by a relatively high mortality rate, thereby becoming a huge challenge for efficient diagnosis and therapy [2]. Among these pathogenic and opportunistic protozoa, free-living amoebae (FLA) are a conspicuous group with a pattern of primary existence as free-living organisms in nature. They occasionally invade a host and live as parasites within the host tissue, which explains why they are also called amphizoic amoebae [3]. FLA can cause localized systemic diseases and disseminated infections. The skin, eyes, lungs, kidneys, and sinuses are all predilection sites. However, the most misleading and

Received December 21, 2020; accepted April 25, 2021

Correspondence: Xunjia Cheng, xjcheng@shmu.edu.cn almost always fatal infections caused by FLA are those "brain-eating" ones of the central nervous system (CNS) occurring in immunocompetent and immunocompromised individuals, such as patients with AIDS [4].

From the numerous genera of FLA in nature, some are extensively known to cause CNS diseases in humans and animals. Among them are several species of Acanthamoeba (such as Acanthamoeba castellanii and Acanthamoeba culberstoni) and only one species of three genera, namely, Balamuthia (Balamuthia mandrillaris), Naegleria (Naegleria fowleri) and Sappinia (Sappinia pedata). The former three genera are also the dominant FLA pathogens for humans and animals $[3,5]$. Known as a "brain-eating" amoeba, $N$. fowleri is the causative agent for the invasive and fulminating fatal form of meningoencephalitis called primary amoebic meningoencephalitis (PAM), which primarily occurs in healthy children and young adults [6]. By contrast, Acanthamoeba and B. mandrillaris are responsible for a chronic infection in immunocompetent and immunocompromised hosts known as granulomatous amoebic encephalitis (GAE). S. pedata has been identified 
in only one case of an immunocompetent male in Texas, USA, causing a unique GAE encephalitis with a favorable clinical outcome. The causative agent of this amoebaassociated encephalitis case was originally identified as Sappinia diploidea, whereas an affiliation to Sappinia pedata has later been proven through molecular biology $[7,8]$. Some recently described FLA species have also been discovered to invade humans and other animals occasionally. Among them, Paravahlkampfia francinae is the only species in its genus known to cause infection in the CNS. The species was isolated from the cerebrospinal fluid (CSF) of a patient with PAM-like symptoms, which is usually caused by N. fowleri [9].

\section{Phylogeny and classification}

Amoebae were first described shortly after the invention of the microscope. Since then, increasing numbers of amoebae have been named, described, and classified [10]. Nevertheless, before the innovation of molecular phylogeny, a great variety of FLA were generally described and sorted in the Rhizopoda clade of the Sarcodina supergroup in the original classification [11]. Morphological traits such as pseudopodium type, cell shape at different life stages, and amoeboid movements were extensively used for the subdivided FLA classification at that time [12]. In recent years, molecular evidence and an associated re-evaluation of morphology have enabled a more molecular-based and a more validated morphological-based classification on the relationships among higherlevel groups of amoebae, leading to the revision and improvement in FLA classification [13,14]. Given the much richer databases of $18 \mathrm{~S}$ rRNA gene sequences, they have become the most extensively used marker gene for the single-gene phylogeny investigation of FLA. Moreover, the burgeoning technology of mitochondrial genome sequencing has been implemented in a series of studies and shown to serve as a potent and scientific source of information for an evolutionary and phylogenetic classification. However, available data remain insufficient to this day, with only several dozens of mitochondrial genomes for FLA $[15,16]$. As a result, FLA have been classified into four clades in the eukaryotic tree of life, focusing primarily on Amoebozoa, Excavata, and to a lesser extent, Rhizaria and Opisthokonta [14,17].

Among the four clades of amoeba, Amoebozoa is the most studied and diverse clade with a gross estimate of about 17000 species [18]. Along with the systematic implementation of high-throughput sequencing technology, a reconstructed phylogenetic classification enables a more detailed overview of Amoebozoa supergroup diversity and taxonomic relationships [19,20]. Acanthamoeba spp. and B. mandrillaris, as single-celled, flattened naked amoebae causing CNS diseases, belong to Amoebozoa in the line of Order Acanthopodida, Class
Centramoebia, Phylum Discosea, Amoebozoa clade in the Amorphea domain of eukaryotic organisms. Among Excavata, Class Heterolobosea encompasses approximately 140 described species [21]. Compared with Amoebozoa, molecular approaches that contribute to confirm a detailed taxonomy within the clade remain lacking for these Heterolobosea groups. Heterolobosea are widely known mostly because of the representative $N$. fowleri with the line of Family Vahlkampfiidae, Order Schizopyrenida, Class Heterolobosea, Phylum Percolozoa, Excavata clade in the Amorphea domain of eukaryotic organisms [22]. Molecular and morphological evidence also systematically and extensively supports the diversity of other FLA's phylogenetic classification. There are two remaining genera that cause CNS infection, S. pedata (Order Thecamoebida, Class Flabellinia, Phylum Discosea) and $P$. francinae (Family Vahlkampfiidae, similar to the orientation of $N$. fowleri).

Lacking distinctive morphological or behavioral characters, FLA such as filose and reticulose cercozoans are found in the Rhizaria clade with a scattered distribution in different phylogenetic groups. A clear estimate or reliable formulation of FLA diversity affiliated with Rhizaria remains lacking $[23,24]$. According to the revisions of classification and diversity in 2019, FLA in Opisthokonta are incorporated in two well-supported clades named Holozoa and Nucletmycea [14,25].

\section{Biology and ecology}

Most FLA such as the above-mentioned Acanthamoeba spp., B. mandrillaris, and S. pedata have two developmental stages: the trophozoite as a nutrition feeding form and the cyst as a resting form. With a general size of some dozens of microns, the trophozoite is an infective stage engaged in amoeboid locomotion, whereas a cyst is a dormant stage against the harsh environment with a smaller size of about more than $10 \mu \mathrm{m}$ [26]. Some amoebae like Naegleria spp. have an additional flagellate stage; the trophozoite transforms into this temporary motile stage when a nutritional deficiency occurs in the environment, but water is present [27]. With a length ranging within $10-16 \mu \mathrm{m}, N$. fowleri's flagellate stage is usually pyriform. They neither divide nor feed, generally reverting to trophozoites within an hour or less. As a metabolically active stage, the trophozoite feeds primarily on Grampositive and Gram-negative bacteria, as well as on algae, fungi, and other protozoa [28]. Sometimes they even feed on relatively large organisms, such as nematodes and planktonic rotifers in aquatic systems [29,30]. The trophozoite multiplies by binary fission and sometimes actively and constantly changes its size and shape [26]. In most FLA such as Acanthamoeba and Naegleria, cysts generally have two layers: the ectocyst and the endocyst. The ectocyst forms during the initial stage of encystment 
and appears as an amorphous and discontinuous layer. Although the endocyst varies in shape such as polygonal or spherical, it has a tiny granular texture with a more consistent and thicker structure than the former [31,32]. Flush pores have been found in the cyst wall of $N$. fowleri. Some species like $B$. mandrillaris even have a third layer between the outer and inner ones as the mesocyst in an amorphous shape. These structures may contribute to the resistance to biocides contained in contact lenses and bronchoscope disinfectants, as well as chlorination and sterilization agents of domestic water systems and hospital water-treatment networks [33-36]. Encystment occurs under the conditions of imbalanced $\mathrm{pH}$, unsuitable osmotic pressure, or inadaptable temperature; it also occurs under nutritional deficiency and in the presence of antiamoeba agents [37]. By contrast, FLA excyst when environmental conditions become favorable again.

FLA are omnipresent in soils, freshwater, marine waters, inside vertebrates, and on the aerial parts of plants and animals [38]. They have also been isolated from human volunteers' nasal mucosa and CSF $[39,40]$. The abundance and diversity of these protists in the environment are strongly related to temperature, moisture, precipitation, $\mathrm{pH}$, and nutrient availability [41]. As the main predators controlling bacterial populations in soils, FLA are more abundant in the rhizospheric zone and the surrounding bulk soil because plants allow the growth of various plant parasites such as bacteria and fungi on which amoebae feed. However, they may also further penetrate the vadose zone of groundwater systems, especially where bacterial populations have reached a high density. In water, a flagellate stage enables some FLA to swim at liberty, whereas others have to be attached to suspended particulates [38]. Attached FLA are also spread throughout water columns in the first $30 \mu \mathrm{m}$ of the water surface or on the bodies of submerged animals and plants. Given the need for attachment, FLA often live on biofilms and at water-soil, water-air, water-plant interfaces. This life habit of living at interfaces further results in difficulty distinguishing their attributive environments. Biofilms such as those on contact lenses and dental-unit waterlines are supportive to FLA growth $[42,43]$. Some genera such as Acanthamoeba spp. and Naegleria spp. have been detected as well in treated waters like drinking water, tap water, cooling towers, swimming pools, hydrotherapy pools, and domestic water systems [35,44-46]. Unconventional water sources such as sewage and aquaria are also not spared from them [47].

Among all pathogenic FLA leading to human encephalitis, several species such as Acanthamoeba, B. mandrillaris, and $N$. fowleri are the dominant ones of concern and are thus massively studied (Table 1). In two forms of encephalitis, $N$. fowleri acts as the agent causing PAM, whereas Acanthamoeba spp. and B. mandrillaris are identified to be the causative organisms of GAE.

\section{Naegleria fowleri in PAM}

The genus name Naegleria was first coined by Alexeieff in 1912 [48]. Forty-five years later, the earliest case of $N$. fowleri infection was found in Australia [49]. Up to 2019, around 430 cases of PAM have been reported worldwide, with the USA and South Asia having the two most conspicuous infection areas $[35,50,51]$. Evaluation of the origin and evolution of Naegleria has revealed more than 40 species within the genus, whereas $N$. fowleri is the only known species to infect humans and cause disease in the CNS. Numerous studies on the molecular and genetic characteristics of Naegleria spp. have been conducted in recent years; some $N$. fowleri genomes such as ATCC 30863 and ATCC 30894 are already publicly available, and others can be obtained by requesting the authors $[52,53]$. Based on the length of the internal transcribed spacer 1 and a $1 \mathrm{bp}$ transition in the 5.8S rDNA, the most accepted system for the identification of $N$. fowleri species was created in 2011, which revealed the existence of at least eight different genotypes unevenly distributed throughout different continents $[54,55]$. Without evidence of virulence differences among various $N$. fowleri types, three genotypes (I, II, and III) are found in the USA, seven genotypes (II, III, IV, V, VI, VII, and VIII) are found in Europe, two genotypes (II and III) are found in mainland Asia, and only one genotype (V) is found in the Oceania and Japan. Five of these eight genotypes (I, II, III, IV, and V) have been confirmed to cause PAM in patients $[56,57]$.

\section{Invasion pathways and pathogenesis}

PAM targets the human CNS as water is identified to be the most frequent route of infection in most PAM cases [51,58]. During recreational water activities such as swimming, diving, and water skiing, $N$. fowleri has the ability to intrude into the human body by entering the nose due to splashing or forcing of contaminated water within the nasal cavity. In the form of trophozoites, infectivity is initiated with the attachment onto the nasal mucosa, followed by the locomotion along the olfactory nerve and cribriform plate. The chemotactic response to nerve-cell components then leads to the arrival on the olfactory bulbs in the CNS [59-61]. As a result, the tissue necrosis and neuron destruction caused by $N$. fowleri are reflected in the ingestion of brain tissue, the release of cytolytic molecules, and the fierce immune response of the host, giving rise to severe inflammation $[62,63]$. However, individuals can also be infected through a dry pathway of entering the nasal passages by cyst-laden dust followed by excysting and reaching the CNS similar to water infection $[51,64]$. When contaminated dust alights on the eye, cysts may also enter the nasal part through the nasolacrimal ducts [51]. As these dry infections tend to occur in regions with higher temperatures like those in South Asia, people living in 
Table 1 Comparative features of three free-living amoebae and their pathogenic role in amoebic encephalitis

\begin{tabular}{|c|c|c|c|}
\hline & Naegleria fowleri & Acanthamoeba spp. & Balamuthia mandrillaris \\
\hline Trophozoite stage & $\begin{array}{l}\text { Diameter } 10-30 \mu \mathrm{m} \text {, speed } \\
\text { about } 1.0 \mu \mathrm{m} / \mathrm{s}\end{array}$ & $\begin{array}{l}\text { Diameter } 15-35 \mu \mathrm{m} \text {, speed } \\
0.3-0.4 \mu \mathrm{m} / \mathrm{s}\end{array}$ & $\begin{array}{l}\text { Diameter } 10-60 \mu \mathrm{m}, \text { speed about } \\
0.25 \mu \mathrm{m} / \mathrm{s}\end{array}$ \\
\hline Cyst stage & $\begin{array}{l}\text { Diameter } 7-15 \mu \mathrm{m} \text {, cysts not } \\
\text { formed in brain tissue }\end{array}$ & $\begin{array}{l}\text { Diameter } 10-15 \mu \mathrm{m} \text {, cysts } \\
\text { formed in brain tissue }\end{array}$ & $\begin{array}{l}\text { Diameter } 10-30 \mu \mathrm{m} \text {, cysts formed } \\
\text { in brain tissue }\end{array}$ \\
\hline Flagellate stage & Transformed from trophozoites & Not found & Not found \\
\hline Environmental habitat & Warm fresh waters, soil, dust & $\begin{array}{l}\text { Freshwater, soil, dusty air, } \\
\text { hospital and household } \\
\text { environments }\end{array}$ & Soil, freshwater \\
\hline CNS infection & $\begin{array}{l}\text { Primary amoebic } \\
\text { meningoencephalitis (PAM) }\end{array}$ & $\begin{array}{l}\text { Granulomatous amoebic } \\
\text { encephalitis (GAE) }\end{array}$ & GAE \\
\hline Susceptible host & $\begin{array}{l}\text { Immunocompetent children } \\
\text { and young adults }\end{array}$ & $\begin{array}{l}\text { Mainly immunocompromised } \\
\text { individuals }\end{array}$ & $\begin{array}{l}\text { Immunocompetent and } \\
\text { immunocompromised individuals }\end{array}$ \\
\hline Portal of entry & Olfactory neuroepithelium & $\begin{array}{l}\text { Nasopharyngeal or cutaneous } \\
\text { epithelium }\end{array}$ & Mainly in cutaneous epithelium \\
\hline Incubation period & Days & Weeks to months & Weeks to months, even years \\
\hline Clinical manifestations & $\begin{array}{l}\text { Headache, fever, nausea, nuchal } \\
\text { rigidity, personality changes, } \\
\text { seizures, coma, behavioral } \\
\text { abnormality }\end{array}$ & $\begin{array}{l}\text { Headache, irritability, fever, } \\
\text { nausea, seizures, confusion, } \\
\text { ataxia, hemiparesis, abnormal } \\
\text { behavior }\end{array}$ & $\begin{array}{l}\text { Headache, irritability, fever, nausea, } \\
\text { stiff neck, sinus infection, behavioral } \\
\text { abnormality }\end{array}$ \\
\hline CSF & $\begin{array}{l}\text { Elevated WBCs, generally low } \\
\text { glucose level and high protein } \\
\text { concentration, detected } \\
\text { trophozoite, no flagellate } \\
\text { or cyst }\end{array}$ & $\begin{array}{l}\text { Elevated WBCs and protein, } \\
\text { hydrocephalus, generally low } \\
\text { glucose level }\end{array}$ & $\begin{array}{l}\text { Elevated WBCs and protein, generally } \\
\text { low glucose level }\end{array}$ \\
\hline Neuroimaging & $\begin{array}{l}\text { Cerebral edema, multifocal } \\
\text { parenchymal and pseudotumor } \\
\text { lesions, nonspecific and unhelpful }\end{array}$ & $\begin{array}{l}\text { Single and multiple space- } \\
\text { occupying or ring-enhancing } \\
\text { lesions, not specific }\end{array}$ & $\begin{array}{l}\text { Single and multiple space-occupying or } \\
\text { ring-enhancing lesions, not specific }\end{array}$ \\
\hline Diagnosis & $\begin{array}{l}\text { CSF examination for trophozoites } \\
\text { and polymorphonuclear leukocytes, } \\
\text { neuroimaging CT and MRI, } \\
\text { polyclonal and monoclonal } \\
\text { antibodies, PCR assays }\end{array}$ & $\begin{array}{l}\text { Microscopic staining, } \\
\text { immunofluorescent microscopy, } \\
\text { neuroimaging CT and MRI, } \\
\text { PCR assays, trophozoite and cyst }\end{array}$ & $\begin{array}{l}\text { Microscopic staining, immunofluores- } \\
\text { cent microscopy, neuroimaging, PCR } \\
\text { assays, metagenomic deep sequen- } \\
\text { cing, unsuitable for isolation and } \\
\text { culture in vitro, trophozoite and } \\
\text { cyst }\end{array}$ \\
\hline Epidemiology & $\begin{array}{l}\text { Worldwide distribution } \\
\text { especially warm regions, hot } \\
\text { summer months }\end{array}$ & $\begin{array}{l}\text { Worldwide distribution, any time } \\
\text { of year }\end{array}$ & Mainly on American continent \\
\hline Estimated cases & $>300$ & $>200$ & $\sim 200$ \\
\hline Case fatality rate & $>95 \%$ & $>90 \%$ & $>90 \%$ \\
\hline Therapy & $\begin{array}{l}\text { Amphotericin B, azithromycin, } \\
\text { chlorpromazine, miltefosine, } \\
\text { rifampin, miconazole and } \\
\text { fluconazole }\end{array}$ & $\begin{array}{l}\text { Voriconazole, sulfadiazine, } \\
\text { fluconazole, pentamidine, } \\
\text { itraconazole, rifampin, } \\
\text { meropenem, flucytosine, } \\
\text { liposomal amphotericin B, } \\
\text { and miltefosine }\end{array}$ & $\begin{array}{l}\text { Fluconazole, pentamidine, sulfadiazine, } \\
\text { itraconazole, rifampin, azithromycin, } \\
\text { flucytosine, linezolid, liposomal } \\
\text { amphotericin } \mathrm{B} \text {, and miltefosine }\end{array}$ \\
\hline Prognosis & Poor & Poor & Poor \\
\hline
\end{tabular}

WBC, white blood cell; CSF, cerebrospinal fluid; CT, computerized tomography; MRI, magnetic resonance imaging; PCR, polymerase chain reaction.

these areas are particularly at risk because they can do little to avoid inhaling cysts. Fortunately, due to the considerably higher incidence of nasal contact than the relevant cases of PAM dry infection, a threshold effect seems to exist because numerous activated amoebae are required for valid penetration into the epithelium and invasion into the brain. Thus, a high probability of cyst exposure may not equate with a high risk of PAM disease [51].
The factors associated with the pathogenesis of $N$. fowleri infection can be direct and indirect [65]. Direct factors include contact-dependent mechanisms involving adherence and phagocytosis and contact-independent mechanisms involving various cytopathic enzymes. Conversely, indirect factors include phenotypic switching, morphology, ubiquity, physiologic tolerance, chemotaxis, and drug resistance. As the primary step for parasite 
cytopathogenicity, adherence onto target cells is one of the first events during the invasion of $N$. fowleri $[66,67]$. A comparison between pathogenic $N$. fowleri and another nonpathogenic Naegleria reveals a differential ability of adhesion and invasion [68]. Mediated by adhesins expressed on the surface of $N$. fowleri, fibronectin (FN) is considered an important extracellular matrix (ECM) protein involved in the adherence onto epithelial cells [69]. Furthermore, FN receptors are known to be integrins, so two integrin-like amoebic proteins are described as colocalized to the focal adhesion-like structures assisting in the adherence of $N$. fowleri [68]. In the study, a $60 \mathrm{kDa}$ FN binding protein is observed to play a significant role in amoeba-mediated host cell cytotoxicity, and protein kinase $\mathrm{C}$ in $N$. fowleri is identified to improve the ability of adherence and cytotoxicity on host cells as a downstream component of integrin-like protein. With the impact of anti-integrin antibody, the reduced ability of $N$. fowleri to bind to ECM further supports this point [68]. A $23 \mathrm{kDa}$ plasma membrane protein is probably involved in the cytotoxicity of $N$. fowleri [70]. In binding assays of different multivalent lectins, carbohydrates are also identified to participate in adherence and cytotoxicity $[71,72]$. The carbohydrate expression of $N$. fowleri and $N$. gruberi are confirmed to be differential, among which the expression of mannose residues is essential for $N$. fowleri adherence onto the nasal mucosa.

Cytopathic enzymes play a crucial role in PAM progression. Early in the initial stage of penetrating the mucous layer, enzymes with mucinolytic activity like a 37 $\mathrm{kDa}$ cysteine protease may contribute to the avoidance of the host response of $N$. fowleri $[73,74]$. Mucin secretion is suggested to be an important protective barrier against infection, whereas one study has shown that the mucinolytic activity of $N$. fowleri is prominently higher than $N$. gruberi that leads to evasion. Naegleriapores A and B, two pore-forming polypeptides of $N$. fowleri processed from separate multipeptide precursor structures, have been found to share similar structural properties with antimicrobial and cytolytic polypeptides [75]. The glycosylation degree of these naegleriapores also reflects their stability against degradation by proteases [76]. Phospholipases are found to be related to the extensive demyelinization in the white matter of PAM patients, and lysophospholipase and sphingomyelinase are identified as factors inflicting damage to the lipid-rich cytoplasmic membrane of cells and the demyelinization of nerve tissue after several years $[77,78]$. Neuraminidase activity, detected in pathogenic $N$. fowleri, is related to reported glycolipid alterations in demyelinating diseases, and the activity is maximal at $\mathrm{pH}$ 4.5-5.0 and is ion independent [79]. Although the role of cysteine proteases in $N$. fowleri has not been clearly defined, they are also suggested to participate in PAM progression [80]. The capability of $N$. fowleri to induce lactate dehydrogenase release and intracellular reactive oxygen species (ROS) accumulation reportedly gives rise to the death of host target cells [81]. Another study has revealed that electrodense granules are secreted by $N$. fowleri trophozoites in the course of brain-tissue invasion, and then they make contact with epithelial cells or collagen substrates to cause damage [82]. Trophozoites of $N$. fowleri are found to produce nitric oxide (NO) in vitro and react to the $\mathrm{NOS}_{2}$ antibody, suggesting that $\mathrm{NO}$ may participate in PAM pathogenesis [83].

$N$. fowleri's capacity of active locomotion and phagocytosis of various host cells also involve host-cell damage $[66,84]$. As a sucker apparatus protruding from the surface of $N$. fowleri, food cups play an important role in the piecemeal consumption of target cells $[85,86]$. Along with polymerization from monomeric G-actin into filamentous F-actin, the consumption process is actin dependent, and a $360 \mathrm{bp} n f a 1$ gene has been identified to be expressed on pseudopodia encoding Nfal protein with a size of 13.1 $\mathrm{kDa}$ [87]. Several years later, one study has further supported the idea that anti-Nfa1 antibody and gene silencing of $n f a l$ could reduce host-cell damage induced by $N$. fowleri [88-90]. As phagocytosis depends on the dynamics of cytoskeleton rearrangements, myosin and tubulin have been identified in trophozoites, whereas actin exists in the cytoplasm, pseudopodia, and food-cup structures [91]. Consisting of a $1.2 \mathrm{kbp}$ coding sequence, the nf-actin gene produces a $50 \mathrm{kDa}$ recombinant fusion protein (Nf-actin), which has been found to cluster in the food-cup structures of $N$. fowleri under fluorescence microscopy [92]. The phagocytic activity of nf-actinoverexpressing $N$. fowleri is sharply increased compared with that of control groups comprising wild-type ones.

\section{Host immune response}

N. fowleri is an FLA existing worldwide, so numerous individuals are exposed to $N$. fowleri in the course of their lives, either through direct contact such as soil or water or through wind-blown cysts landing on the nasal mucosa. In a study implemented among Czechoslovakian students and psychiatric patients, the positive antibody to Naegleria is detected to range from $1 \%$ to $4 \%$. Conversely, another study implemented in the USA exhibits a much higher percentage of positive responses to the pathogenic $N$. fowleri and the nonpathogenic Naegleria lovaniensis, i.e., more than $80 \%$ of serum samples from hospitalized patients [93,94]. In general, because of the swiftness of PAM and the rarity of surviving patients, the comprehension of the mechanisms underlying early immune failure and the factors leading to subsequent fulminant inflammation is challenging. Fortunately, a remarkable similarity exists between PAM animal models and human infections [63].

Although the mechanism of PAM pathogenesis is not well understood, innate and adaptive immune responses 
have been identified to participate in the defense against $N$. fowleri invasion [95]. However, N. fowleri belongs to eukaryotes instead of bacteria or viruses, so most mammalian pattern-recognition receptors do not recognize it as foreign. During the initial stages of infection, the host response is activated by the secretion of mucus trapping the trophozoites, and mucus contains mucin as the major component $[61,73]$. Mucus is considered as an effective protective barrier resisting most PAM erosion, and invasion occurs only when the number of amoebae is overwhelmingly sufficient to the innate immune response (Fig. 1A). Early in respiratory epithelial cells, the activation of innate defense has been induced by $N$. fowleri, leading to ROS production and then expressing the MUC5AC gene and protein, as well as the pro-inflammatory mediators interleukin- 8 (IL-8) and interleukin- $1 \beta$ (IL13) [96]. The canonical Toll-like receptor (TLR) 4 pathway has also been demonstrated to express and produce the proinflammatory cytokines and $\beta$ defensin- 2 in a timedependent manner [97]. Eosinophils and neutrophils participate in the inflammatory process induced by trophozoite invasion, and activated neutrophils play notable roles in early-stage infections [61]. Neutrophils surround $N$. fowleri through contact-dependent and contact-independent mechanisms and then engulf them $[62,65,98]$. Moreover, although a single neutrophil is insufficient for phagocytosing an entire $N$. fowleri, the cluster of several neutrophils is adequate to rupture $N$. fowleri by pinching off and engulfing them part by part. Complement activation especially that mediated by antibodies has been identified to enhance neutrophil activity against amoebae, and the cleavage products of complement also play a role as a chemotactic impetus for immune-cell recruitment $[99,100]$. Tumor necrosis factor$\alpha(\mathrm{TNF}-\alpha)$ augments neutrophil activity by enhancing the production of oxygen radicals that destroy $N$. fowleri [101]. DNA, myeloperoxidase, histones, and elastase enzymes are all found to play roles in the definitive mechanism of neutrophils [102]. The feature of macrophages in the host defense against $N$. fowleri has also been demonstrated, among which microglial cells are the ones located in the brain [103]. During exposure to $N$. fowleri lysates, microglial cells release TNF- $\alpha$, IL-1 $\beta$, and IL-6, whereas astrocytes lead to AP-1 activation and the subsequent expression of IL- $1 \beta$ and IL- 6 in an extracellular signal-regulated kinase, c-Jun N-terminal kinase, and p38 mitogen-activated protein kinase (MAPK) dependent pathway [104].

Due to the swift and lethal disease course of PAM, research on the adaptive immune response to $N$. fowleri infection is difficult (Fig. 1B). Circulating antibodies have been identified as the dominant protective adaptive immune mechanism by immune serum-transfer experiments $[105,106]$. Among them, immunoglobulin M (IgM) is the primary antibody isotype generated by $N$. fowleri infection [2]. Although IgM contributes to the agglutination of $N$. fowleri and complement activation, its function is severely hindered by its high molecular weight of about $900 \mathrm{kDa}$, which confers difficulty in crossing the bloodbrain barrier (BBB) [107]. Together with polymorphonuclear cells (PMNs), IgA and IgG antibodies could reportedly avoid the attachment of $N$. fowleri to the nasal epithelium [108-110]. Secretory immunoglobulin A (SIgA) can inhibit the binding of $N$. fowleri to collagen type I and block the proliferation of $N$. fowleri $[111,112]$. By forming neutrophil extracellular traps, IgG mediates PMN activation, which may be a crucial antimicrobial response against $N$. fowleri [113]. The ability to stimulate the migration and maturation of antigen-presenting cells (APCs) such as macrophages and dendritic cells is related to the enhanced adaptive immune response against $N$. fowleri [114]. Amoebic surface antigens seem to favor Tindependent responses, and cell-mediated immunity against $N$. fowleri is observed in the form of delayedtype hypersensitivity [115]. Unfortunately, further studies on the functionality of amoeba-specific $\mathrm{CD} 4^{+} \mathrm{T}$ cells are still lacking.

$N$. fowleri has evolved a series of effective mechanisms to cause the evasion of the host immune system, so early failure occurs in the detection of parasites and the use of effective antiamoeba mechanisms [62]. Except for the mucolytic activity toward nasal mucosa, virulent $N$. fowleri are resistant to subsequent complement-mediated lysis by expressing complement-regulatory proteins and shedding a membrane-attack complex from C5b to $\mathrm{C} 9$ on vesicles $[106,116,117]$. N. fowleri can also evade host immune defenses by internalizing surface-bound antibodies. For example, the antigen-antibody complex of SIgA can be eradicated from the surface of $N$. fowleri by capping and then internalizing surface-bound antibodies $[112,118,119]$. As opposed to the early stage, the host immune system activates an acute inflammatory reaction against $N$. fowleri in the later course of PAM, which plays a crucial role in inflicting damage to CNS tissue [2,65]. At this stage, macrophages of the olfactory region are inclined to recruit an intense neutrophil influx [120]. With all the acute inflammatory cytokines produced by local and recruited leukocytes, the release of various tissue-destructive lysosomal products induces extensive cerebral edema and neuronal tissue damage. Acute inflammatory cells that are recruited as part of chemotaxis exhibit a release reaction of lysosomes and cytokines, causing the activation of the complement cascade. This process contributes to the $\mathrm{BBB}$ breach and further results in extensive cerebral damage in PAM patients (Fig. 1C). After BBB breach, neutrophils and macrophages become the predominant leukocytes infiltrating in the neural tissue. Stimulated by fowlerstefin, microglial cells also produce proinflammatory cytokines through the nuclear factor- $\kappa \mathrm{B}-$ and AP-1dependent MAPK signaling pathways, and then they can 


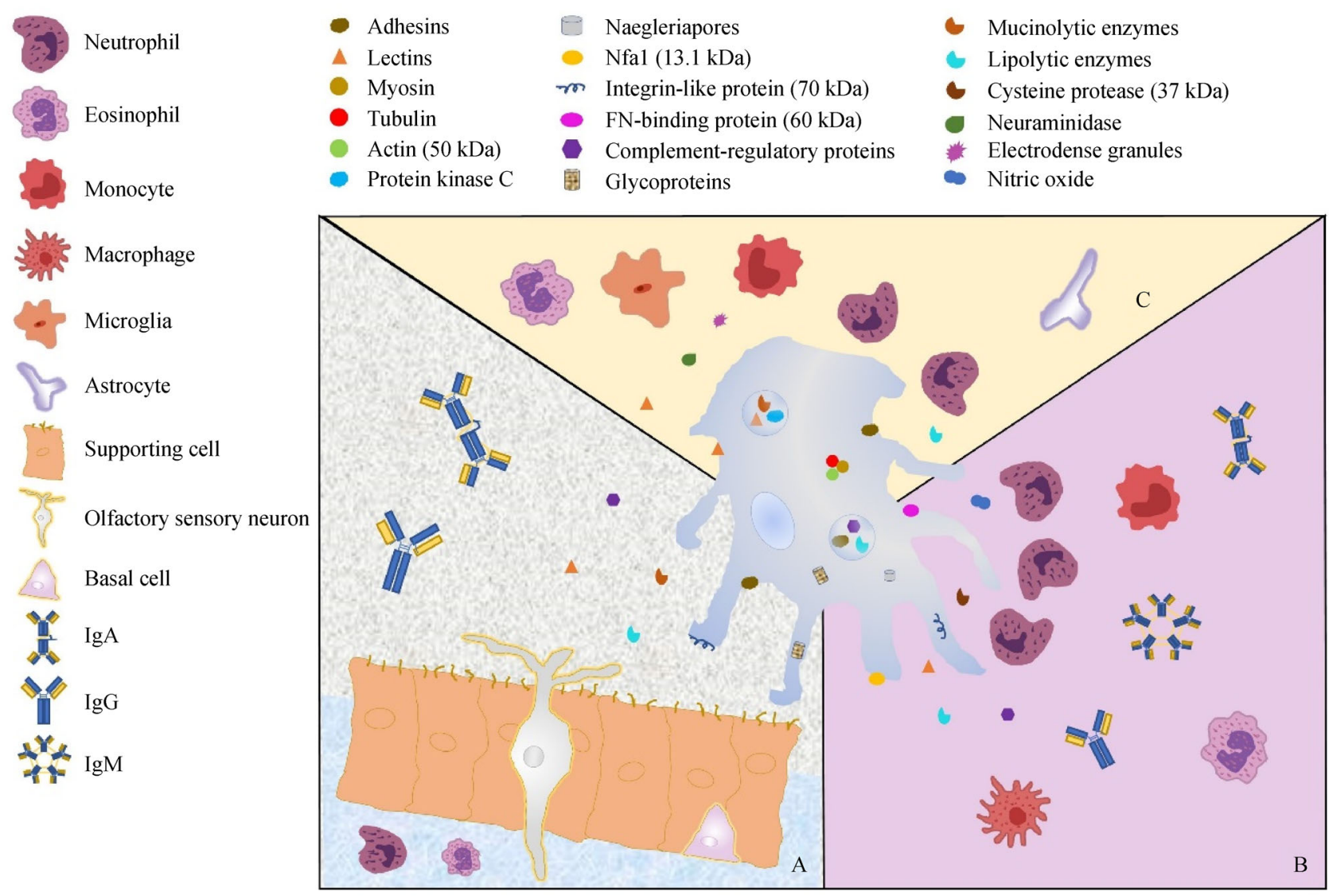

Fig. 1 Model of parasite molecules and host components in invasion by $N$. fowleri. (A) Representative scheme of olfactory epithelium invasion by trophozoites. As the primary step of contact, the penetration into the mucous layer occurs when trophozoite number is overwhelmingly sufficient in the presence of parasite molecules, including adhesins, lectins, and mucinolytic enzymes. Once the barrier is disrupted, trophozoites attach, separate, and lyse epithelial cells moving toward the basal lamina with the participation of lectins, lipolytic enzymes, complement-regulatory proteins, integrin-like proteins, protein kinase C, naegleriapores, $N$. fowleri antigen-related protein 1 (Nfa1), and actin. IgA, IgG, and IgM with the ability of potentially obstructing the attachment to the olfactory epithelial surface are secreted in the airway. (B) Representative scheme of trophozoites invasion in blood. Trophozoites follow the blood stream and carry out adherence and cytotoxicity toward blood-brain barrier. Similar to those participating in epithelial invasion, the parasite molecules involved in the endothelial invasion process include cysteine protease, fibronectin-binding protein, naegleriapores, carbohydrates, complement-regulatory proteins, lipolytic enzymes, Nfa1, and nitric oxide. Trophozoites induces lactate dehydrogenase release and intracellular reactive oxygen species (ROS), whereas ROS is related to the expression of MUC5AC gene and protein and the proinflammatory mediators interleukin- 8 and interleukin- $1 \beta$. Except for various circulating antibodies, neutrophils, eosinophils, monocytes, and macrophages are activated in response. The canonical Toll-like receptor 4 pathway expresses and produces proinflammatory cytokines and $\beta$ defensin- 2 in a timedependent manner. (C) Representative scheme of trophozoite invasion in cerebrospinal fluid. After gaining access to neuron and gliacyte, trophozoites proliferate and finally provoke an acute inflammatory reaction consisting of monocytes, neutrophils and eosinophils, resulting in damage to CNS tissue. Parasite molecules such as actin, neuraminidase, and lipolytic enzymes are involved in the process. Considering that a single neutrophil is insufficient for phagocytosing an entire parasite, the cluster of several neutrophils is needful as a reinforcement and activity can be enhanced by tumor necrosis factor- $\alpha$ and complement activation.

exacerbate the inflammatory response in tissues infected with $N$. fowleri [121].

\section{Pathophysiology and clinical manifestations}

Neurological symptoms of PAM present as acute and fulminating hemorrhagic meningoencephalitis, which occurs primarily in healthy children and young adults having a contact history with contaminated water and also in other individuals like infants [122,123]. The disease generally starts within 5-7 days from the initial contact and sometimes as short as $24 \mathrm{~h}$ [2]. Initially, a sudden onset of PAM symptoms occurs; these symptoms include severe bifrontal or bitemporal headaches, nuchal rigidity, chills, and high fever, followed by nausea, vomiting, weakness, fatigue, or behavioral abnormalities including restlessness and irritability [57,124-126]. Except for nuchal rigidity, other positive meningeal irritation signs including the Kernig sign and Brudzinski sign can also be detected sometimes along with the Babinski sign [127]. As the 
disease progresses, it leads to photophobia and later neurological abnormalities, such as lethargy, confusion, coma, diplopia, seizures, and bizarre behavior $[2,126,128]$. Cranial nerve palsies may be the sign of brain edema and herniation with intracranial pressure for $600 \mathrm{~mm} \mathrm{H}_{2} \mathrm{O}$ or even higher. Finally, patients die within a week.

Analysis of predilection sites in brains of $N$. fowleri infection has revealed that the frontal lobe is the most favorable destination in the majority of cases, followed by the parietal lobe and corticomedullary junction [129]. Hydrocephalus is also observed in $27 \%$ of selected cases. The observed lesion sites include the base of the orbitofrontal and temporal lobes, base of the brain, posterior fossa, hypothalamus, midbrain, pons, medulla oblongata, and upper portion of the spinal cord [130,131]. Autopsies of PAM cases demonstrate that the cerebral hemispheres are usually soft, swollen, edematous, and severely congested with severely congested leptomeninges $[2,132,133]$. Limited purulent exudates can be found microscopically within the cerebral hemispheres, base of the brain, brainstem, cerebellum, and upper portion of the spinal cord, which contain primarily neutrophils followed by eosinophils, macrophages, and lymphocytes [134]. Olfactory bulbs and orbitofrontal cortices reveal changes such as hemorrhagic necrosis surrounded by purulent exudates [2]. Numerous $N$. fowleri trophozoites without the presence of polymorphonuclear leukocytes can be found in edematous and necrotic neural tissues; sometimes they also appear in Virchow-Robin spaces with the ability of surrounding blood vessels but not causing an inflammatory response. Brain tissue, meninges, and CSF are all suitable for $N$. fowleri proliferation, and the amoebae can be detected and cultured from brain tissue and CSF samples obtained postmortem [26,135]. By contrast, flagellates or cysts in brain tissue and CSF have not yet been detected [136].

\section{Diagnosis}

Due to the lack of distinctive clinical features, PAM is easily confused with other bacterial or viral meningoencephalitis in most cases; thus, a complete and precise clinical history is essential for diagnosis. Relevant information should contain any recent patient contact with freshwater and history of upper respiratory tract diseases such as rhinitis and allergies, especially in children and young adults [67]. In early-stage $N$. fowleri infection, a computed tomography (CT) scan is usually performed, and then it leads to cerebral edema with obliteration of cisterns as the disease progresses. The sulci and adjacent gray matter are also intensely enhanced with a normal-sized ventricle [137]. Combined with the images of magnetic resonance imaging (MRI), multifocal parenchymal lesions, pseudotumor lesions, hemorrhagic infarcts, meningeal exudates, and necrosis are visible in the brains of PAM patients with edema and hydrocephalus $[67,138]$. Unfortunately, these neuroimaging methods cannot distinguish meningitis cases with different etiologies from one another [139].

Among PAM cases infected with $N$. fowleri, $63.7 \%$ are diagnosed postmortem and $36.3 \%$ are diagnosed premortem, whereas microscopy is implemented successfully in $36.4 \%$ of postmortem cases [129]. Thus, observing motile amoeba trophozoites in CSF samples by microscopy is the most extensively and successfully used premortem diagnostic method. Generally, CSF may have a relatively high pressure with low glucose and high protein concentration, whereas lumbar puncture can be performed under the condition of low CSF pressure [3]. The CSF of PAM patients exhibits various abnormal colors ranging from gray and yellowish-white in early-stage infection to red in the later stage of infection due to the significant increase of erythrocytes [57,140,141]. During PAM, the count of erythrocytes can increase from 250 cells per $\mathrm{mm}^{3}$ to 24600 cells per $\mathrm{mm}^{3}$ [2]. By staining the fixed samples with Giemsa, Wright, trichrome, periodic acid-Schiff, or hematoxylin and eosin (H\&E), microscopic examination can reveal the presence of trophozoites in CSF $[26,142,143]$. However, Gram staining is not applied in the diagnosis due to its uncharacteristic amoebic nuclear morphology [3,144]. Sometimes $N$. fowleri can be confused with macrophages, so their nucleus that contains a large, central, and round nucleolus starts to become important for distinguishing from host cells $[133,142]$. Moreover, in the early stage of PAM, N. fowleri are probably invisible and polymorphonuclear leukocytes can be observed in the CSF primarily comprising neutrophils. Phase-contrast microscopy is beneficial for optimizing amoeba visualization $[139,145]$. Monoclonal antibodies with the capability of recognizing a glycosylated epitope on $N$. fowleri have been used to diagnose PAM infections [146]. The technique can specifically identify $N$. fowleri in $\mathrm{CSF}$ and serum and distinguish $N$. fowleri from other Naegleria species, even from other FLA in various samples [147-149]. Molecular techniques such as polymerase chain reaction (PCR), nested PCR, quantitative PCR, and multiplex PCR assays are more sensitive, rapid, and specific for $N$. fowleri detection in clinical and environmental samples [57,125,150-152]. A PCR assay can also reportedly detect $N$. fowleri successfully in formalin-fixed paraffin-embedded brain sections [153]. Compared with quantitative PCR, next-generation droplet digital PCR already exhibits better specificity [154].

\section{Epidemic situation, therapy, and prognosis}

As a globally distributed pathogen, $N$. fowleri is detected throughout all continents except Antarctica, especially in warmer equatorial countries [54]. Generally, most PAM cases are acquired through recreational activities such as swimming, diving, and water sports in freshwaters 
containing amoebae [50]. Nasal irrigation and ritual nasal ablution by using tap water are also highly correlated in some countries, such as India or Pakistan [35,155]. In temperate countries such as those in northern and eastern Europe, the growing environments of $N$. fowleri are limited in waters warmed either artificially or naturally. Although $N$. fowleri are inclined to be more active in warmer regions, fewer cases are reported in extremely warm areas [50]. Meanwhile, except for the most frequent water-infection route, dry infection can also occur through cyst-laden dust entering the nasal passages. Dry infections tend to occur in hot regions with a percentage of $8 \%$ in the Indian subcontinent, whereas it is almost $0 \%$ in the USA [51]. With a highly seasonal life cycle, $N$. fowleri has been proven to grow at $30{ }^{\circ} \mathrm{C}$ to $46{ }^{\circ} \mathrm{C}$. Although trophozoites degenerate within several hours below $10^{\circ} \mathrm{C}$, cysts can survive at $4{ }^{\circ} \mathrm{C}$ for nearly 6 months [156-158]. Due to global warming, average temperatures have increased and large areas have hugely changed as either increased drought conditions or increased precipitation leads to the erosion and eutrophication of freshwater courses. Considering that habitats favored by $N$. fowleri are increasing, climate change may inevitably result in the geographic spread of the amoebae and increased PAM incidence [159]. Moreover, because of the misdiagnosis and lack of autopsies, PAM is suspected to be much more common than currently indicated, especially in developing countries $[58,160]$. Through the isolation of $N$. fowleri from the resident's nares, it has been suggested that PAM epidemiology is much more serious in warm and dry regions, such as India and Nigeria [161-163].

Given that PAM is rarely confirmed during early-stage infection, the untimely treatment of this acute and fulminating infection contributes to a high mortality rate of more than $90 \%$ [65]. Additionally, because of the low incidence of PAM and economic constraints especially in developing countries, interest in the development of such anti-PAM drugs is lacking despite the utmost need. A deficiency exists in clinical trials assessing the efficacy of one therapeutic method over another [164]. Along with the improvement of research on drug use, amphotericin B has been identified as the primary choice used alone or in combination with other drugs for treating PAM. In an in vitro study, an amphotericin B concentration of at least $0.1 \mu \mathrm{g} / \mathrm{mL}$ can suppress more than $90 \%$ of $N$. fowleri growth, whereas $0.39 \mu \mathrm{g} / \mathrm{mL}$ can completely suppress its proliferation [165]. As the cornerstone of therapy, the intravenous dose of amphotericin B is $1.5 \mathrm{mg} / \mathrm{kg} /$ day in two divided doses for 3 days followed by $1 \mathrm{mg} / \mathrm{kg} / \mathrm{day}$ once daily for an additional 11 days, whereas the intrathecal dose of amphotericin B is $1.5 \mathrm{mg}$ /day for 2 days followed by $1 \mathrm{mg} /$ day for an additional 8 days as recommended by the Centers for Disease Control and Prevention [164]. Due to the various side effects of amphotericin B such as anemia, fever, nausea, and dose- related nephrotoxicity, new formulations with improved toxicity profiles, such as deoxycholate amphotericin B with a very low minimum inhibitory concentration of $10 \%$, have been developed [65]. To reduce side effects, amphotericin B is also used in combination with other drugs, such as azithromycin, chlorpromazine, miltefosine, rifampin, and fluconazole [80,165-168]. Animal trials on experimental mice exhibit survival rates of $40 \%, 75 \%$, and $55 \%$ with amphotericin, chlorpromazine, and miltefosine, respectively [166]. A recent study has indicated that auranofin may also be effective for PAM treatment either as a monotherapy or in combination with the standard amphotericin B [169]. Furthermore, though there are a series of clinical guidelines for amoebic meningoencephalitis, physicians usually adjusts the combinations of various classes of drugs with different action mechanisms for liberal and individualized therapies [129].

\section{Acanthamoeba spp. and Balamuthia mandrillaris in $\mathrm{GAE}$}

Genus Acanthamoeba was created by Volkonsky in 1931. Acanthamoeba species were initially classified into three distinct groups (I-III) according to their morphology and cyst size, but this classification was considered unreliable due to variations in culture environments [170]. Nine years later, a modified classification of three groups (I-III) was proposed by analyzing the following three isoenzymes: hexokinase, esterase, and acid phosphatase [171]. Since then, pathogenic and nonpathogenic Acanthamoeba have been differentiated based on the differentiation of protein and antigen profile [172]. To date, 22 genotypes (T1-T22) have been identified and designated according to the comparison of sequences of the nuclear 18S rRNA gene [173]. Genotypes T1, T2, T4, T5, T10, and T12 are responsible for causing meningitis in humans, whereas genotype $\mathrm{T} 4$ appears to be the most prevalent and predominant one characterized by increased virulence and decreased sensitivity to chemotherapeutic agents [174-176]. Additionally, about 31 species have been described and placed within genus Acanthamoeba up to 2020, among which 18 species are reportedly pathogenic or implicated in the medical field. These species are $A$. polyphaga, A. palestinensis, $A$. castellanii, A. rhysodes, $A$. astronyxis, A. culbertsoni, A. griffini, A. lenticulata, A. royreba, A. divionensis, A. lugdunensis, A. quina, A. triangularis, A. healyi, A. stevensoni, A. jacobsi, A. hatchetti, and $A$. byersi $[173,177-192]$.

$B$. mandrillaris was initially considered by some people as an innocuous soil organism, and all GAE cases were identified to be caused by Acanthamoeba, yet brain tissue from some cases could not react with Acanthamoebaspecific immunohistochemical tests [193-195]. As an organism associated with soils, soil exposure has been identified as an important risk factor for Balamuthia 
infection, but its isolation from soil is especially difficult because only several prior occasions have been reported in Iran, Peru, and USA [196-198]. The first report of B. mandrillaris causing disease is described in a pregnant mandrill monkey with meningoencephalitis at the San Diego Zoo in 1986, and then the amoeba was identified as a human pathogen four years later [199]. Except for primates, Balamuthia has also been reported to cause infection in various other animals such as horses and dogs [200-202]. As the only known pathogenic species infecting humans within the genus, all $B$. mandrillaris are demonstrated to belong to one single genotype through nuclear and mitochondrial rDNA analysis [203]. With no diversification among different isolates, $B$. mandrillaris exhibits a low genetic-variation level $[149,204,205]$.

\section{Invasion pathways and pathogenesis}

Through the inhalation of air or aspiration of water contaminated with invasive forms of these amoebae, Acanthamoeba infection generally begins with the penetration of the upper respiratory tract and damaged or ulcerative skin, whereas lesions on cutaneous epithelium act as the most common sites for the initial B. mandrillaris infection [206-209]. Ocular cornea, oral mucosa, and intestinal mucosa are also possible sites for Acanthamoeba infection, whereas the gastrointestinal tract has been demonstrated as a possible route for the entry of B. mandrillaris [2,210,211]. Moreover, B. mandrillaris can spread through organ transplantation [212,213]. An important migration route of Acanthamoeba and B. mandrillaris to the CNS is through the nasal mucous membrane, the endothelium of capillaries in the brain, and the ethmoid bone along olfactory nerves [214-217]. These two amoebae also cause cutaneous and respiratory infections, and Acanthamoeba is responsible for an additional ocular infection named amoebic keratitis $[218,219]$. Unfortunately, the hematogenous spread is a precondition for $\mathrm{BBB}$ invasion, so it makes GAE pathogenesis especially complicated and remains unclear to date $[220,221]$.

Similar to $N$. fowleri in PAM, factors determining the CNS pathogenicity of Acanthamoeba spp. and B. mandrillaris can also be divided into direct and indirect ones [222]. Direct agents are related to adherence, interaction, and the secretion of enzymes that are cytotoxic to human neurons. For Acanthamoeba, attachment onto the surface of host tissue is identified as the crucial step to establish infection, later culminating in the host cell's death [223]. With the use of cytochalasin B (CB) and latrunculin B (LB), actin cytoskeleton has been revealed to participate in the adherence onto neuronal cells [224]. The main mechanism of action of cytochalasin and latrunculin is to decrease the polymerization rate of actin. With the CB and LB treatment of trophozoites, the normal distribution of actin filaments changes and the acanthopodia of Acanthamoeba disintegrate, thereby presenting remarkable inhibition of trophozoite adhesion. After Acanthamoeba trophozoites cross the olfactory epithelium, Schwann cells (SCs) are probably some of the first target cells protecting the olfactory nerve bundles [225]. The study reveals that the interaction between Acanthamoeba and SC could result in $\mathrm{SC}$ autophagy or necrosis. This interaction is characterized primarily by contact-dependent mechanisms including intimate contact and phagocytosis through the emission of cytoplasmic projections, such as amoebostomes. Appearing as sucker-like structures on various amoebic surfaces, amoebostomes play an active role in lysing and engulfing different targets [226,227]. As the entry sites of Acanthamoeba into the brain, the BBB is momentous for studies on invasion [228,229]. Different pathogens own various modes of $\mathrm{BBB}$ crossing from intracellular to paracellular. As an efficient method of distinguishing transcellular routes, measuring the integrity of the BBB exhibits high transendothelial electrical resistance (TEER) [230]. Through interaction with human brain microvascular endothelial cells, Acanthamoeba decrease TEER values to almost zero, causing a Rho-dependent reduction of ZO-1 and occlusion similar to that in N. fowleri [231]. Mannose-binding protein and extracellular serine proteases also play a role in the traversal process of Acanthamoeba [232]. Furthermore, evidence including host cell DNA laddering, chromatin condensation, membrane blebbing, and formation of apoptotic bodies suggests that Acanthamoeba induce apoptosis in neuroblastoma cells, thereby presenting a mechanism for host cell death other than phagocytosis [233]. One study has shown that Acanthamoeba induces apoptosis through caspase-dependent and caspase-independent pathways with the overexpression of the proapoptotic protein Bax. As a highly diverse set of proteolytic enzymes, M28 aminopeptidase secreted by Acanthamoeba spp. has sufficiently high virulence to inflict host damage and induce the apoptosis of cell lines [234]. Besides, two 130 and $150 \mathrm{kDa}$ proteases from an Acanthamoeba isolate reportedly induce GAE, and both of them exhibit maximal activity at neutral $\mathrm{pH}$ and over a range of temperatures [235]. These proteases degrade ECM components in the CNS such as collagen I, collagen III, elastin, and plasminogen, as well as casein and hemoglobin.

Like Acanthamoeba, multiple elements may be involved in $B$. mandrillaris pathogenesis, including adhesion to cells, secretion of enzymes, penetration of the BBB, and host inflammatory responses [236,237]. However, information on the pathogenic mechanisms of $B$. mandrillaris remains limited [216]. The amoebic invasion of the brain probably occurs through $\mathrm{BBB}$ breakage or migration along nerve fibers, and $\mathrm{BBB}$ may act as the most possible site for the invasion of B. mandrillaris into the CNS [217]. Adhesion, proteolytic attack, and host inflammatory 
responses may all contribute to BBB disruption, whereas normal human serum (NHS) is protective against amoebae $[238,239]$. In turn, by specifically activating phosphatidylinositol 3-kinase, B. mandrillaris can induce human brain microvascular endothelial cells to release IL-6, which later participates in initiating the early inflammatory response as a pleiotropic cytokine [240]. B. mandrillaris has been demonstrated to have the capability to recognize and interact with specific ECM glycoproteins, such as collagen-1, laminin-1, and FN [241]. As metalloprotease activity is found in two isolates of Balamuthia, the proteolytic activities of amoebae to degrade ECM have also been ascertained [242]. B. mandrillaris may possess the ability to hydrolyze extracellular ATP through its surface enzymes like ecto-ATPase [243].

As a multifactorial process, the ability of Acanthamoeba and $B$. mandrillaris to induce human encephalitis also depends on their capacity to survive outside the mammalian host for various times and under diverse environmental conditions $[222,239]$. These indirect factors include encystment ability, morphology, ubiquity, tolerance to unsuitable environmental conditions, chemotaxis, and drug resistance. Except for the biological and ecological ones mentioned above, the pathogenicity of amoebic trophozoites may also be related to the number of pseudopodia that allow connection with host cells [244]. The ability of these amoebae to grow at diverse temperatures, osmolalities, and $\mathrm{pH}$ is positively correlated with their prevalence in various environments and pathogenicity. For example, although some nonpathogenic strains with high thermal tolerance have been described, pathogenic species among Acanthamoeba spp. exhibit generally better thermal tolerance than nonpathogenic ones [2,245].

\section{Host immune response}

On account of the ubiquitous distribution of Acanthamoeba and B. mandrillaris in nature, contact with humans and other animals with trophozoites, cysts, or their antigens can widely elicit antibodies to these amoebae in serum. For example, contact with Acanthamoeba appears to be common because the presence of their antibodies has been proven in serum samples from relevant patients and many asymptomatic healthy individuals [94,124]. As an opportunistic pathogen, the ability of Acanthamoeba and B. mandrillaris to produce diseases in the CNS depends on their own virulence and on host susceptibility and environmental conditions. A competent immune system is generally sufficient to defeat pathogens under normal circumstances. However, due to the complexity of the host immune system and low numbers of GAE infections, the precise factors that contribute to host resistance and associated mechanisms remain unclear.

Innate and adaptive immune responses have been demonstrated to participate in the Acanthamoeba infection [115,246] (Fig. 2A). TLRs play an important role in recognizing amoebae and inducing cytokine production. As an example, increased levels of TLR2 and TLR4 mRNA expression have been found in the brains and lungs of mice infected with Acanthamoeba, suggesting the effect of these receptors on immune-response initiation [247,248]. The complement system works as a barrier to infections and activates a cascade system that destroys invading Acanthamoeba in GAE. As the first line of defense against protozoa, the complement system is activated through the classical pathway, alternative pathway, or mannose-binding lectin pathway [222]. A recent experiment on mice has suggested that the alternative pathway plays a major role in Acanthamoeba lysis, whereas the trigger molecules of the lectin pathway and classical pathway are not essential in complement activation [249]. In vitro studies with NHS exhibit the lytic activity of complement and antibodies against Acanthamoeba, and the lytic pathway is highly effective in the presence of phagocytes, such as macrophages and neutrophils $[250,251]$. These interactions further stimulate the secretion of proinflammatory cytokines such as IL-1 $\beta$ and TNF- $\alpha$ released from monocytes and macrophages, leading to the activation of neutrophils and vascular endothelial cells $[252,253]$. However, the effect exerted by Acanthamoeba trophozoites appears to be complex because they can stimulate and inhibit cytokine production [254]. They induce IL-10, IL-8, IL-6, and TNF- $\alpha$ release in monocytes while inhibiting TNF- $\alpha$ and IL- 8 production by macrophages. TNF- $\alpha$ has been shown to induce the encystation of Acanthamoeba, which in turn makes them resistant to phagocytosis. Macrophages have been found to be involved in initiating and maintaining an effective immune response and play a role in tissue repair [255]. A significant increase in natural killer cells is observed in mice infected with Acanthamoeba, suggesting that these cells also participate in the body's protection against the amoebae $[256,257]$. As a result, complement proteins are induced to be deposited, the opsonization of amoebae is induced and then taken up by phagocytes, and the membrane attack complex ultimately forms, leading to the death of target cells [222].

Antibodies to B. mandrillaris have been detected in serum samples of GAE patients and healthy individuals, and cord blood also contains antibodies at a lower titer [258,259] (Fig. 2B). Although serum exerts a protective effect against the combination and destructive activities of B. mandrillaris, the amoebicidal effect is relatively limited because only about $40 \%$ of trophozoites are killed $[239,260]$. The protective role of antibodies is still underresearched because several GAE patients with a high titer of antibodies to B. mandrillaris have no positive protection response [261]. Regarding the inflammatory response, leukocytes are recruited to the sites of infection by 


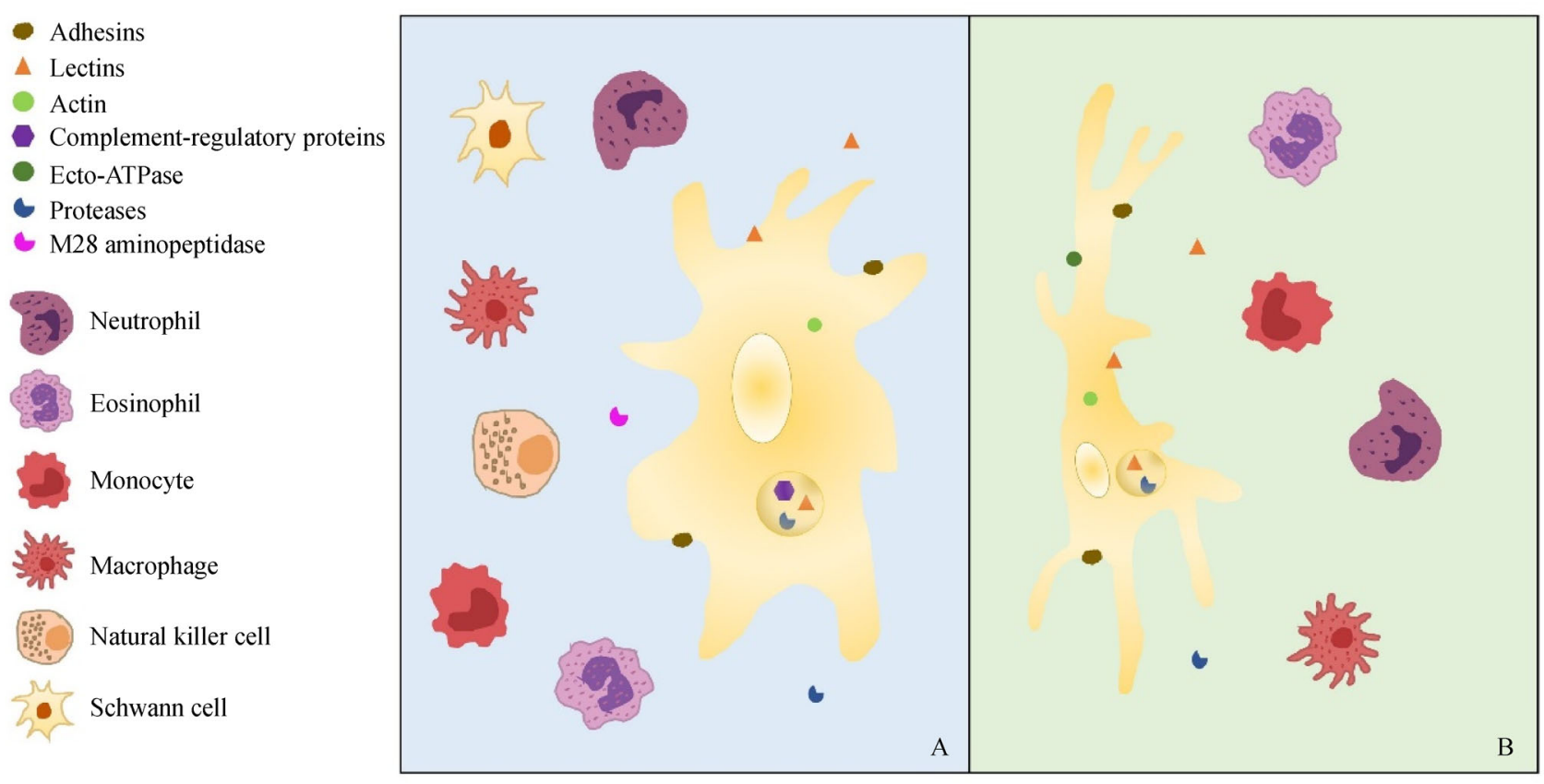

Fig. 2 Model of parasite molecules and host components in invasion by Acanthamoeba spp. and B. mandrillaris. (A) Representative scheme of invasion by Acanthamoeba spp. trophozoites. Infection generally begins with penetration into nasopharyngeal or cutaneous epithelium. Trophozoites attach onto the host-tissue surface and induce apoptosis and phagocytosis in the presence of parasite molecules, such as adhesins, lectins, proteases, complement-regulatory proteins, and actin cytoskeleton. Schwann cells are some of the first target cells with the outcome of autophagy or necrosis. Mannose-binding protein and extracellular serine proteases are related to the traversal process of the blood-brain barrier. Toll-like receptors recognize the trophozoites and induce cytokine production, whereas the alternative pathway plays the major role in Acanthamoeba lysis by activating the complement system. Neutrophils, eosinophils, monocytes, macrophages, and natural killer cells are activated in response, among which monocytes are induced to release IL-10, IL- 8 , IL- 6 , and TNF- $\alpha$, whereas macrophages are inhibited to release IL- 8 and TNF- $\alpha$. (B) Representative scheme of invasion by $B$. mandrillaris trophozoites. Parasite molecules involved in the invasion process include adhesins, lectins, proteases, ecto-ATPase, and actin. In the CNS, trophozoites induce the release of IL-6 by specifically activating phosphatidylinositol 3-kinase, and IL-6 later participates in initiating an early inflammatory response as a pleiotropic cytokine. Neutrophils, eosinophils, monocytes, and macrophages are recruited to the sites of infection. Type IV hypersensitivity reaction, including the exocytosis of tissues and the release of matrix-damaging enzymes, occurs in Acanthamoeba spp. and B. mandrillaris invasion.

modulating the expression of various adhesion molecules, such as intercellular adhesion molecule-1. Among leukocytes, macrophages have recently been identified to have no inhibitory effect on the biological properties of B. mandrillaris through in vitro experiments, and they even increase the amoebic binding and cell cytotoxicity mediated by protozoa [262]. Furthermore, lectins such as mannose- and galactose-binding proteins are involved in host damage mediated by Acanthamoeba and B. mandrillaris, respectively [263].

Given that Acanthamoeba and B. mandrillaris do not have adequate time to be stationed in the cerebral circulation and invade the brain, they can provoke BBB breach despite not actually invading the brain tissue. Brain damage is actually evoked by the amplified host immune responses [120]. The presence of a hardly phagocytable or unphagocytable microorganism and an integrated cellular immunity is critically needed to induce granuloma formation and associated tissue destruction [264,265]. With a general size of about $25 \mu \mathrm{m}$, Acanthamoeba spp. and B. mandrillaris are incapable of phagocytosis, and the amoebic antigens being exposed to the immune system tend to set up an ideal scenario for type IV hypersensitivity reaction, including the exocytosis of tissues and the release of matrix-damaging enzymes [120]. The human immune response plays an important part in breaching the BBB and damaging the brain in GAE.

\section{Pathophysiology and clinical manifestations}

Although Acanthamoeba spp. rarely leads to CNS infections, their prognosis is very poor, with less than 10 documented survivors out of more than 150 reported cases [266]. Balamuthia GAE is also a highly fatal disease with fewer than $10 \%$ of patients surviving [208]. GAE caused by Acanthamoeba generally occurs among immunocompromised individuals with AIDS and those who are chronically ill, diabetic, having undergone organ transplantation, or debilitated for other reasons (e.g., taking steroids, antibiotics, and chemotherapeutic medications) 
[4,135,267-269]. Immunocompetent individuals are much less likely to be infected because only 11 patients are immunocompetent in the approximately 150 documented cases of Acanthamoeba GAE [266,270,271]. By contrast, GAE caused by $B$. mandrillaris occurs in healthy and immunocompromised individuals, among which children and young adults are the most vulnerable populations [208,266,272-276]. Similar to viral or bacterial meningitis, the clinical symptoms of GAE usually start with headache, irritability, nausea, dizziness, and low-grade fever. It progresses to other neurological symptoms, including altered mental state, seizures, confusion, aphasia, lethargy, hallucination, focal neurologic signs, diplopia, cranial nerve palsies, ataxia, hemiparesis, stiff neck, and personality changes $[2,4,124,208,269,271,275,277-282]$. Facial palsy and numbness are also common in Acanthamoeba GAE as important causes of facial asymmetry. Moreover, some patients affected with $B$. mandrillaris in Peru exhibit skin lesions as common symptoms, whereas the general symptoms in other regions' cases are relatively absent during the cutaneous stage of GAE [275,283]. As a progressive disease, death due to GAE generally occurs within 1-2 months because of the onset of symptoms owing to the increased intracranial pressure. The disease can also sometimes develop over a period lasting for several years [135,284].

As to the predilection sites of Acanthamoeba and $B$. mandrillaris infection in the brain, the majority of Acanthamoeba cases involve the cerebral cortices, with the frontal and the temporal lobes being the most affected, followed by the parietal and occipital lobes [129]. The temporal lobe is the most vulnerable as observed in Balamuthia cases, followed by other sites such as the frontal, parietal, and occipital lobes. The cerebellum and the corticomedullary junction are the most favored targets among extracortical sites in Acanthamoeba GAE, whereas the thalamus is the most affected target followed by the corticomedullary junction, cerebellum, and basal ganglia among extracortical sites in Balamuthia GAE. Additionally, hydrocephalus is observed in a few Acanthamoeba GAE resulting from the blockage of CSF drainage. Unfortunately, premortem diagnosis cannot guarantee survival because the patients have often already suffered from intense damage in the brain before diagnosis. Microscopic examinations of CNS sections obtained from autopsies of Acanthamoeba and B. mandrillaris GAE cases reveal changes such as edema, encephalomalacia, tonsillar herniation, and multiple necrotic and hemorrhagic areas [135,285]. Hemorrhagic infarcts can be seen in areas such as the brainstem, cerebral hemispheres, and cerebellum. Multinucleated giant cells are also commonly seen in the brainstem, cerebral hemispheres, cerebellum, midbrain, and basal ganglion. Blood vessels may be occasionally seen as being cuffed by amoebic trophozoites and cysts, and angiitis can exist with surrounding perivascular inflammatory cells, among which reactive macrophages are usually mistaken for amoebae $[3,26]$. Given the deficiency of cellular immune response, a granulomatous response may be absent or minimal in immunocompromised patients [286]. Many of these patients develop a series of skin lesions, abscesses, or erythematous nodules on their body and limbs, especially patients with AIDS. In the skin lesions, amoebic trophozoites and cysts with a single nucleus can be seen. The nodules are usually firm and nontender but are also sometimes ulcerated and purulent $[2,124,135,222,287]$. In a few cases of immunocompetent patients invaded by Acanthamoeba, the infection has not even spread to the CNS [288,289].

\section{Diagnosis}

Due to the nondirectional symptoms and rarity of the disease, GAE may usually be confused with other bacterial leptomeningitis or viral meningitis. Brain lesions can be detected by neuroimaging methods such as CT and MRI, but their results are not specific, resulting in limited diagnostic value for GAE [3,290]. Single or multiple enhanced lesions are often seen in the cerebral cortex, basal ganglia, cerebellum, and subcortical white matter through $\mathrm{CT}$, whereas multifocal lesions and ring-like patterns of enhancement are seen in the diencephalon, thalamus, brain stem, and posterior fossa structures through MRI in patients with GAE; edema and hydrocephalus are also visible [4,217,266,269,291-294]. Intralesional hemorrhage has been observed in some GAE neuroimaging findings. Amoebic encephalitis has been suggested to be listed in the differential diagnosis for immunocompromised patients with new brain lesions found on radiographic imaging [295].

Microscopy with some staining such as calcofluor white, acridine orange, or $\mathrm{H} \& \mathrm{E}$ of host brain tissue can be used to detect trophozoites and cysts of Acanthamoeba and $B$. mandrillaris. However, morphological features are insufficient for differentiating the exact amoeba genus, which is problematic as it requires expertise. Samples generally originate from CSF, brain-tissue biopsy, sinus or lung biopsy, and skin lesions on the face or extremities obtained either after surgery or postmortem [222,296]. Notably, a negative CSF sample cannot exclude the possibility of GAE infection in suspected patients [297]. As antiamoeba antibodies are found in the serum of healthy and GAEinfected individuals, several immunodiagnostic tests have been well developed and put into application. Immunofluorescent microscopy and indirect immunofluorescent and immunoenzymatic assays (e.g., flow cytometry and enzyme-linked immunosorbent assay) have been successfully used to examine serum and tissue samples [3,298301]. However, given that Acanthamoeba can be isolated from patients' tissues and then cultured in vitro, this 
method is unsuitable for $B$. mandrillaris because they grow slowly and require the culture of tissue cells as a food source $[139,302]$. Developing molecular techniques such as PCR, multiplex PCR, and real-time PCR are extensively used to identify Acanthamoeba and B. mandrillaris in the CSF and brain-tissue samples for many years $[4,151,174$, 175,269,295,303-305]. These molecular assays are effective diagnostic techniques that can be implemented for rapid and sensitive identification even in formalin-fixed paraffin-embedded brain biopsy specimens, so it is beneficial for the appropriate and timely treatment of patients infected with GAE [306]. Metagenomic deep sequencing has also been applied for the diagnosis of amoebic encephalitis in recent years [307].

\section{Epidemic situation, therapy, and prognosis}

The number of either Acanthamoeba or B. mandrillaris GAE cases worldwide exceeds $200[124,136]$. Among them, Acanthamoeba cases reportedly have the highest number of infected patients in North America and India, whereas $B$. mandrillaris cases are found throughout the entire American continent [208,276,284,308-312]. However, compared with the opportunities for humans and other animals to make contact with these amoebae, the number of GAE cases is relatively much smaller. Through breaks in the skin contaminated by soil or through the upper respiratory tract blown by the wind or air currents, infection generally starts with the entry of the protozoa $[2,135,311]$. Water may also serve as a vehicle for transmission because Acanthamoeba and B. mandrillaris have been detected in a series of water samples and reported to cause disease in humans and other animals [201,313-315]. B. mandrillaris can also be transmitted through organ transplantation [316,317]. Balamuthia GAE appears to be more frequent in Hispanics, but further research is still needed to determine whether the unequal incidence is a simple coincidence [318].

Additionally, because of nonspecific symptoms similar to other bacterial or viral diseases and the difficulty in diagnosis at an early stage resulting from the deficiency of reliable diagnostic tests and clinicians' nonfamiliarity with FLA, more than $90 \%$ of GAE cases are fatal [284]. The majority of GAE cases are detected postmortem, further resulting in the lack of recommended treatment and management patterns. Except for surgery, the treatment of GAE is still based on limited in vitro experimental data and clinical experiences reported in literature [319-321]. According to reported cases with therapeutic success, various drugs are usually given alone or in combination, including voriconazole, fluconazole, itraconazole, rifampin, meropenem, linezolid, liposomal amphotericin B, trimethoprim-sulfamethoxazole, moxifloxacin, caspofungin, and miltefosine, yet treatment may be successful only at early stages [2,26,124,208,222,290,322-325]. Some agents such as quinoline nitroxoline are also considered potent against pathogenic amoebae [326]. Most agents exhibit low sensitivity to the amoebae or are unable to sufficiently cross the BBB into the CNS. Some available agents also exhibit severe side effects, which may result in the disability of GAE survivors [327,328].

\section{Conclusions}

The most successful strategy for the survival and multiplication of parasites is sustainably exploiting their hosts, yet many of these free-living organisms generally cause violent infections and kill the patients. Although rare, encephalitis caused by FLA especially Acanthamoeba, Balamuthia, and Naegleria is eliciting attention as an increasing cause of parasitic death worldwide. The low number of infections caused by FLA is probably due to diagnosis difficulty and the lack of experienced caregivers, so many cases may not have been recognized and diagnosed, especially in regions such as Africa and South Asia where facilities are either minimal or lacking. Along with global warming, ample evidence indicates that the available environmental niches for numerous FLA particularly $N$. fowleri can naturally increase. Meanwhile, the population is continuously growing and areas of human activity are also expanding in some regions. Multiple factors conspire to increased contact between human and FLA, leading to further increased number of infections. Patients with amoebic encephalitis in various regions usually have different clinical characteristics and prognoses. Considering that PAM and GAE are almost always fatal as less than $10 \%$ of patients are reported to survive, the cure rate urgently needs improvement through immediate diagnosis and early treatment. Studies focused on interactions between pathogenic amoebae and their host contribute to the development of various novel therapeutic drugs against the parasites. However, although numerous new findings have been reported in recent years, the whole picture is far from being complete and a series of topics on the pathogenic role of FLA in encephalitis require further research. Indeed, authoritative standards for the clinical diagnosis and early treatment of FLA encephalitis remain lacking. Future work should aim to address these points with investigations focusing on pathogenesis, clinical manifestations, diagnosis, and therapies.

\section{Acknowledgements}

We thank all members of our laboratory for their fruitful discussions and constructive suggestions. We are also grateful to Hiroshi Tachibana for the provision of information.

\section{Compliance with ethics guidelines}

Hongze Zhang and Xunjia Cheng declare no conflict of interest. This 
manuscript is a review article and does not involve a research protocol requiring approval by the relevant institutional review board or ethics committee.

Open Access This article is licensed under a Creative Commons Attribution 4.0 International License, which permits use, sharing, adaptation, distribution and reproduction in any medium or format, as long as you give appropriate credit to the original author(s) and the source, provide a link to the Creative Commons license, and indicate if changes were made.

The images or other third party material in this article are included in the article's Creative Commons license, unless indicated otherwise in a credit line to the material. If material is not included in the article's Creative Commons license and your intended use is not permitted by statutory regulation or exceeds the permitted use, you will need to obtain permission directly from the copyright holder.

To view a copy of this license, visit https://creativecommons.org/ licenses/by/4.0/.

\section{References}

1. Dye C. After 2015: infectious diseases in a new era of health and development. Philos Trans R Soc Lond B Biol Sci 2014; 369(1645): 20130426

2. Visvesvara GS, Moura H, Schuster FL. Pathogenic and opportunistic free-living amoebae: Acanthamoeba spp., Balamuthia mandrillaris, Naegleria fowleri, and Sappinia diploidea. FEMS Immunol Med Microbiol 2007; 50(1): 1-26

3. Król-Turmińska K, Olender A. Human infections caused by freeliving amoebae. Ann Agric Environ Med 2017; 24(2): 254-260

4. Lau HL, De Lima Corvino DF, Guerra FM Jr, Malik AM, Lichtenberger PN, Gultekin SH, Ritter JM, Roy S, Ali IKM, Cope JR, Post MJD, Gonzales Zamora JA. Granulomatous amoebic encephalitis caused by Acanthamoeba in a patient with AIDS: a challenging diagnosis. Acta Clin Belg 2021; 76(2): 127-131

5. Balczun C, Scheid PL. Free-living amoebae as hosts for and vectors of intracellular microorganisms with public health significance. Viruses 2017; 9(4): E65

6. Zaheer R. Naegleria fowleri - the brain-eating amoeba. J Pak Med Assoc 2013; 63(11): 1456

7. Gelman BB, Popov V, Chaljub G, Nader R, Rauf SJ, Nauta HW, Visvesvara GS. Neuropathological and ultrastructural features of amebic encephalitis caused by Sappinia diploidea. J Neuropathol Exp Neurol 2003; 62(10): 990-998

8. Qvarnstrom Y, da Silva AJ, Schuster FL, Gelman BB, Visvesvara GS. Molecular confirmation of Sappinia pedata as a causative agent of amoebic encephalitis. J Infect Dis 2009; 199(8): 11391142

9. Visvesvara GS, Sriram R, Qvarnstrom Y, Bandyopadhyay K, Da Silva AJ, Pieniazek NJ, Cabral GA. Paravahlkampfia francinae n. sp. masquerading as an agent of primary amoebic meningoencephalitis. J Eukaryot Microbiol 2009; 56(4): 357-366

10. Glöckner G, Noegel AA. Comparative genomics in the Amoebozoa clade. Biol Rev Camb Philos Soc 2013; 88(1): 215-225
11. Bovee EC, Jahn TL. Mechanisms of movement in taxonomy of Sarcodina. 3. Orders, suborders, families, and subfamilies in the superorder Lobida. Syst Zool 1966; 15(3): 229-240

12. Schaeffer AA. Taxonomy of the Amebas; with descriptions of thirty-nine new marine and freshwater species. Washington: The Carnegie Institution of Washington, 1926

13. Smirnov AV, Chao E, Nassonova ES, Cavalier-Smith T. A revised classification of naked lobose amoebae (Amoebozoa: lobosa). Protist 2011; 162(4): 545-570

14. Adl SM, Bass D, Lane CE, Lukeš J, Schoch CL, Smirnov A, Agatha S, Berney C, Brown MW, Burki F, Cárdenas P, Čepička I, Chistyakova L, Del Campo J, Dunthorn M, Edvardsen B, Eglit Y, Guillou L, Hampl V, Heiss AA, Hoppenrath M, James TY, Karnkowska A, Karpov S, Kim E, Kolisko M, Kudryavtsev A, Lahr DJG, Lara E, Le Gall L, Lynn DH, Mann DG, Massana R, Mitchell EAD, Morrow C, Park JS, Pawlowski JW, Powell MJ, Richter DJ, Rueckert S, Shadwick L, Shimano S, Spiegel FW, Torruella G, Youssef N, Zlatogursky V, Zhang Q. Revisions to the classification, nomenclature, and diversity of eukaryotes. J Eukaryot Microbiol 2019; 66(1): 4-119

15. Bondarenko N, Glotova A, Nassonova E, Masharsky A, Kudryavtsev A, Smirnov A. The complete mitochondrial genome of Vannella simplex (Amoebozoa, Discosea, Vannellida). Eur J Protistol 2018; 63: 83-95

16. Corsaro D. Update on Acanthamoeba phylogeny. Parasitol Res 2020; 119(10): 3327-3338

17. Samba-Louaka A, Delafont V, Rodier MH, Cateau E, Héchard Y. Free-living amoebae and squatters in the wild: ecological and molecular features. FEMS Microbiol Rev 2019; 43(4): 415-434

18. Adl SM, Leander BS, Simpson AG, Archibald JM, Anderson OR, Bass D, Bowser SS, Brugerolle G, Farmer MA, Karpov S, Kolisko M, Lane CE, Lodge DJ, Mann DG, Meisterfeld R, Mendoza L, Moestrup Ø, Mozley-Standridge SE, Smirnov AV, Spiegel F. Diversity, nomenclature, and taxonomy of protists. Syst Biol 2007; 56(4): 684-689

19. Cavalier-Smith T, Fiore-Donno AM, Chao E, Kudryavtsev A, Berney C, Snell EA, Lewis R. Multigene phylogeny resolves deep branching of Amoebozoa. Mol Phylogenet Evol 2015; 83: 293304

20. Kang S, Tice AK, Spiegel FW, Silberman JD, Pánek T, Cepicka I, Kostka M, Kosakyan A, Alcântara DMC, Roger AJ, Shadwick LL, Smirnov A, Kudryavtsev A, Lahr DJG, Brown MW. Between a pod and a hard test: the deep evolution of Amoebae. Mol Biol Evol 2017; 34(9): 2258-2270

21. Pánek T, Ptáčková E, Čepička I. Survey on diversity of marine/ saline anaerobic Heterolobosea (Excavata: Discoba) with description of seven new species. Int J Syst Evol Microbiol 2014; 64(Pt 7): 2280-2304

22. Piñero JE, Chávez-Munguía B, Omaña-Molina M, LorenzoMorales J. Naegleria fowleri. Trends Parasitol 2019; 35(10): 848-849

23. Bass D, Chao EE, Nikolaev S, Yabuki A, Ishida K, Berney C, Pakzad U, Wylezich C, Cavalier-Smith T. Phylogeny of novel naked filose and reticulose Cercozoa: Granofilosea cl. n. and Proteomyxidea revised. Protist 2009; 160(1): 75-109

24. Berney C, Romac S, Mahé F, Santini S, Siano R, Bass D. Vampires in the oceans: predatory cercozoan amoebae in marine habitats. 
ISME J 2013; 7(12): 2387-2399

25. Brown MW, Spiegel FW, Silberman JD. Phylogeny of the "forgotten" cellular slime mold, Fonticula alba, reveals a key evolutionary branch within Opisthokonta. Mol Biol Evol 2009; 26(12): 2699-2709

26. Martinez AJ, Visvesvara GS. Free-living, amphizoic and opportunistic amebas. Brain Pathol 1997; 7(1): 583-598

27. Page FC. An illustrated key to freshwater and soil amoebae: with notes on cultivation and ecology. Scientific Publication No. 34. Ambleside: Freshwater Biological Association, 1976: 155

28. Wilkinson DM, Mitchell EAD. Testate amoebae and nutrient cycling with particular reference to soils. Geomicrobiol J 2010; 27(6-7): 520-533

29. Geisen S, Rosengarten J, Koller R, Mulder C, Urich T, Bonkowski M. Pack hunting by a common soil amoeba on nematodes. Environ Microbiol 2015; 17(11): 4538-4546

30. Han BP, Wang T, Lin QQ, Dumont HJ. Carnivory and active hunting by the planktonic testate amoeba Difflugia tuberspinifera. Hydrobiologia 2008; 596(1): 197-201

31. Bowers B, Korn ED. The fine structure of Acanthamoeba castellanii (Neff strain). II. Encystment. J Cell Biol 1969; 41(3): 786-805

32. Anwar A, Khan NA, Siddiqui R. Combating Acanthamoeba spp. cysts: what are the options? Parasit Vectors 2018; 11(1): 26

33. Hughes R, Kilvington S. Comparison of hydrogen peroxide contact lens disinfection systems and solutions against Acanthamoeba polyphaga. Antimicrob Agents Chemother 2001; 45(7): 2038-2043

34. Greub G, Raoult D. Biocides currently used for bronchoscope decontamination are poorly effective against free-living amoebae. Infect Control Hosp Epidemiol 2003; 24(10): 784-786

35. Ali M, Jamal SB, Farhat SM. Naegleria fowleri in Pakistan. Lancet Infect Dis 2020; 20(1): 27-28

36. Rohr U, Weber S, Michel R, Selenka F, Wilhelm M. Comparison of free-living amoebae in hot water systems of hospitals with isolates from moist sanitary areas by identifying genera and determining temperature tolerance. Appl Environ Microbiol 1998; 64(5): 1822-1824

37. Fouque E, Trouilhé MC, Thomas V, Hartemann P, Rodier MH, Héchard Y. Cellular, biochemical, and molecular changes during encystment of free-living amoebae. Eukaryot Cell 2012; 11(4): 382-387

38. Rodríguez-Zaragoza S. Ecology of free-living amoebae. Crit Rev Microbiol 1994; 20(3): 225-241

39. Amann R, Springer N, Schönhuber W, Ludwig W, Schmid EN, Müller KD, Michel R. Obligate intracellular bacterial parasites of acanthamoebae related to Chlamydia spp. Appl Environ Microbiol 1997; 63(1): 115-121

40. Pisani F, Costa C, Oteri G, Ioli A. Identification of amoebae in the CSF in a patient with meningoencephalitis. J Neurol Neurosurg Psychiatry 2003; 74(10): 1445-1446

41. Bass P, Bischoff PJ. Seasonal variability in abundance and diversity of soil gymnamoebae along a short transect in southeastern USA. J Eukaryot Microbiol 2001; 48(4): 475-479

42. Donlan RM, Costerton JW. Biofilms: survival mechanisms of clinically relevant microorganisms. Clin Microbiol Rev 2002; 15(2): 167-193
43. Barbeau J, Buhler T. Biofilms augment the number of free-living amoebae in dental unit waterlines. Res Microbiol 2001; 152(8): 753-760

44. Hoffmann R, Michel R. Distribution of free-living amoebae (FLA) during preparation and supply of drinking water. Int J Hyg Environ Health 2001; 203(3): 215-219

45. Abdul Majid MA, Mahboob T, Mong BGJ, Jaturas N, Richard RL, Tian-Chye T, Phimphila A, Mahaphonh P, Aye KN, Aung WL, Chuah J, Ziegler AD, Yasiri A, Sawangjaroen N, Lim YAL, Nissapatorn V. Correction: Pathogenic waterborne free-living amoebae: an update from selected Southeast Asian countries. PLoS One 2017; 12(5): e0177564

46. Bunsuwansakul C, Mahboob T, Hounkong K, Laohaprapanon S, Chitapornpan S, Jawjit S, Yasiri A, Barusrux S, Bunluepuech K, Sawangjaroen N, Salibay CC, Kaewjai C, Pereira ML, Nissapatorn V. Acanthamoeba in Southeast Asia-overview and challenges. Korean J Parasitol 2019; 57(4): 341-357

47. Visvesvara GS, Stehr-Green JK. Epidemiology of free-living ameba infections. J Protozool 1990; 37(4): 25S-33S

48. Alexeieff A. Sur les charactères cytologiques et la systématique des amibes du groupe limax (Naegleria nov. gen. et Hartmannia nov. gen.) et des amibes parasites des vertebrates (Protamoeba nov. gen.). Bull Soc Zool Fr 1912; 37: 55-74

49. Fowler M, Carter RF. Acute pyogenic meningitis probably due to Acanthamoeba sp.: a preliminary report. Br Med J 1965; 2(5464): 740-742

50. Gharpure R, Bliton J, Goodman A, Ali IKM, Yoder J, Cope JR. Epidemiology and clinical characteristics of primary amebic meningoencephalitis caused by Naegleria fowleri: a global review. Clin Infect Dis 2021; 73(1): e19-e27

51. Maciver SK, Piñero JE, Lorenzo-Morales J. Is Naegleria fowleri an emerging parasite? Trends Parasitol 2020; 36(1): 19-28

52. Zysset-Burri DC, Müller N, Beuret C, Heller M, Schürch N, Gottstein B, Wittwer M. Genome-wide identification of pathogenicity factors of the free-living amoeba Naegleria fowleri. BMC Genomics 2014; 15(1): 496

53. Liechti N, Schürch N, Bruggmann R, Wittwer M. Nanopore sequencing improves the draft genome of the human pathogenic amoeba Naegleria fowleri. Sci Rep 2019; 9(1): 16040

54. De Jonckheere JF. Origin and evolution of the worldwide distributed pathogenic amoeboflagellate Naegleria fowleri. Infect Genet Evol 2011; 11(7): 1520-1528

55. Coupat-Goutaland B, Régoudis E, Besseyrias M, Mularoni A, Binet $\mathrm{M}$, Herbelin P, Pélandakis $\mathrm{M}$. Population structure in Naegleria fowleri as revealed by microsatellite markers. PLoS One 2016; 11(4): e0152434

56. De Jonckheere JF. What do we know by now about the genus Naegleria? Exp Parasitol 2014; 145(Suppl): S2-S9

57. Sazzad HMS, Luby SP, Sejvar J, Rahman M, Gurley ES, Hill V, Murphy JL, Roy S, Cope JR, Ali IKM. A case of primary amebic meningoencephalitis caused by Naegleria fowleri in Bangladesh. Parasitol Res 2020; 119(1): 339-344

58. Yoder JS, Eddy BA, Visvesvara GS, Capewell L, Beach MJ. The epidemiology of primary amoebic meningoencephalitis in the USA, 1962-2008. Epidemiol Infect 2010; 138(7): 968-975

59. Martinez J, Duma RJ, Nelson EC, Moretta FL. Experimental naegleria meningoencephalitis in mice. Penetration of the olfactory 
mucosal epithelium by Naegleria and pathologic changes produced: a light and electron microscope study. Lab Invest 1973; 29(2): 121-133

60. Jarolim KL, McCosh JK, Howard MJ, John DT. A light microscopy study of the migration of Naegleria fowleri from the nasal submucosa to the central nervous system during the early stage of primary amebic meningoencephalitis in mice. J Parasitol 2000; 86(1): 50-55

61. Rojas-Hernández S, Jarillo-Luna A, Rodríguez-Monroy M, Moreno-Fierros L, Campos-Rodríguez R. Immunohistochemical characterization of the initial stages of Naegleria fowleri meningoencephalitis in mice. Parasitol Res 2004; 94(1): 31-36

62. Marciano-Cabral F, Cabral GA. The immune response to Naegleria fowleri amebae and pathogenesis of infection. FEMS Immunol Med Microbiol 2007; 51(2): 243-259

63. Moseman EA. Battling brain-eating amoeba: enigmas surrounding immunity to Naegleria fowleri. PLoS Pathog 2020; 16(4): e1008406

64. Lawande RV, John I, Dobbs RH, Egler LJ. A case of primary amebic meningoencephalitis in Zaria, Nigeria. Am J Clin Pathol 1979; 71(5): 591-594

65. Siddiqui R, Ali IKM, Cope JR, Khan NA. Biology and pathogenesis of Naegleria fowleri. Acta Trop 2016; 164: 375-394

66. Marciano-Cabral FM, Patterson M, John DT, Bradley SG. Cytopathogenicity of Naegleria fowleri and Naegleria gruberi for established mammalian cell cultures. J Parasitol 1982; 68(6): $1110-1116$

67. Martínez-Castillo M, Cárdenas-Zúñiga R, Coronado-Velázquez D, Debnath A, Serrano-Luna J, Shibayama M. Naegleria fowleri after 50 years: is it a neglected pathogen? J Med Microbiol 2016; 65(9): 885-896

68. Jamerson M, da Rocha-Azevedo B, Cabral GA, Marciano-Cabral F. Pathogenic Naegleria fowleri and non-pathogenic Naegleria lovaniensis exhibit differential adhesion to, and invasion of, extracellular matrix proteins. Microbiology (Reading) 2012; 158(Pt 3): 791-803

69. Han KL, Lee HJ, Shin MH, Shin HJ, Im KI, Park SJ. The involvement of an integrin-like protein and protein kinase $\mathrm{C}$ in amoebic adhesion to fibronectin and amoebic cytotoxicity. Parasitol Res 2004; 94(1): 53-60

70. Flores-Huerta N, Sánchez-Monroy V, Rodríguez MA, SerranoLuna J, Shibayama M. A comparative study of the membrane proteins from Naegleria species: a $23-\mathrm{kDa}$ protein participates in the virulence of Naegleria fowleri. Eur J Protistol 2020; 72: 125640

71. Cervantes-Sandoval I, Jesús Serrano-Luna J, Pacheco-Yépez J, Silva-Olivares A, Tsutsumi V, Shibayama M. Differences between Naegleria fowleri and Naegleria gruberi in expression of mannose and fucose glycoconjugates. Parasitol Res 2010; 106(3): 695-701

72. Carrasco-Yepez M, Campos-Rodriguez R, Godinez-Victoria M, Rodriguez-Monroy MA, Jarillo-Luna A, Bonilla-Lemus P, De Oca AC, Rojas-Hernandez S. Naegleria fowleri glycoconjugates with residues of $\alpha$-D-mannose are involved in adherence of trophozoites to mouse nasal mucosa. Parasitol Res 2013; 112(10): 3615-3625

73. Cervantes-Sandoval I, Serrano-Luna JJ, García-Latorre E, Tsutsumi V, Shibayama M. Mucins in the host defence against Naegleria fowleri and mucinolytic activity as a possible means of evasion. Microbiology (Reading) 2008; 154(Pt 12): 3895-3904

74. Cervantes-Sandoval I, Serrano-Luna JJ, García-Latorre E, Tsutsumi V, Shibayama M. Characterization of brain inflammation during primary amoebic meningoencephalitis. Parasitol Int 2008; 57(3): 307-313

75. Herbst R, Ott C, Jacobs T, Marti T, Marciano-Cabral F, Leippe M. Pore-forming polypeptides of the pathogenic protozoon Naegleria fowleri. J Biol Chem 2002; 277(25): 22353-22360

76. Herbst R, Marciano-Cabral F, Leippe M. Antimicrobial and poreforming peptides of free-living and potentially highly pathogenic Naegleria fowleri are released from the same precursor molecule. J Biol Chem 2004; 279(25): 25955-25958

77. Chang SL. Pathogenesis of pathogenic Naegleria amoeba. Folia Parasitol (Praha) 1979; 26(3): 195-200

78. Hysmith RM, Franson RC. Elevated levels of cellular and extracellular phospholipases from pathogenic Naegleria fowleri. Biochim Biophys Acta 1982; 711(1): 26-32

79. Eisen D, Franson RC. Acid-active neuraminidases in the growth media from cultures of pathogenic Naegleria fowleri and in sonicates of rabbit alveolar macrophages. Biochim Biophys Acta 1987; 924(2): 369-372

80. Zyserman I, Mondal D, Sarabia F, McKerrow JH, Roush WR, Debnath A. Identification of cysteine protease inhibitors as new drug leads against Naegleria fowleri. Exp Parasitol 2018; 188: 3641

81. Song KJ, Jang YS, Lee YA, Kim KA, Lee SK, Shin MH. Reactive oxygen species-dependent necroptosis in Jurkat $\mathrm{T}$ cells induced by pathogenic free-living Naegleria fowleri. Parasite Immunol 2011; 33(7): 390-400

82. Chávez-Munguía B, Villatoro LS, Omaña-Molina M, RodríguezMonroy MA, Segovia-Gamboa N, Martínez-Palomo A. Naegleria fowleri: contact-dependent secretion of electrondense granules (EDG). Exp Parasitol 2014; 142: 1-6

83. Rojas-Hernández S, Rodríguez-Monroy MA, Moreno-Fierros L, Jarillo-Luna A, Carrasco-Yepez M, Miliar-García A, CamposRodríguez R. Nitric oxide production and nitric oxide synthase immunoreactivity in Naegleria fowleri. Parasitol Res 2007; 101(2): 269-274

84. Fulton C. Intracellular regulation of cell shape and motility in Naegleria. First insights and a working hypothesis. J Supramol Struct 1977; 6(1): 13-43

85. John DT, Cole TB Jr, Marciano-Cabral FM. Sucker-like structures on the pathogenic amoeba Naegleria fowleri. Appl Environ Microbiol 1984; 47(1): 12-14

86. Tiewcharoen S, Rabablert J, Chetanachan P, Junnu V, Worawirounwong D, Malainual N. Scanning electron microscopic study of human neuroblastoma cells affected with Naegleria fowleri Thai strains. Parasitol Res 2008; 103(5): 1119-1123

87. Shin HJ, Cho MS, Jung SU, Kim HI, Park S, Kim HJ, Im KI. Molecular cloning and characterization of a gene encoding a 13.1 $\mathrm{kDa}$ antigenic protein of Naegleria fowleri. J Eukaryot Microbiol 2001; 48(6): 713-717

88. Kang SY, Song KJ, Jeong SR, Kim JH, Park S, Kim K, Kwon MH, Shin HJ. Role of the Nfa1 protein in pathogenic Naegleria fowleri cocultured with CHO target cells. Clin Diagn Lab Immunol 2005; 12(7): 873-876

89. Song KJ, Jeong SR, Park S, Kim K, Kwon MH, Im KI, Pak JH, 
Shin HJ. Naegleria fowleri: functional expression of the Nfa1 protein in transfected Naegleria gruberi by promoter modification. Exp Parasitol 2006; 112(2): 115-120

90. Lee YJ, Kim JH, Jeong SR, Song KJ, Kim K, Park S, Park MS, Shin HJ. Production of Nfa1-specific monoclonal antibodies that influences the in vitro cytotoxicity of Naegleria fowleri trophozoites on microglial cells. Parasitol Res 2007; 101(5): 1191-1196

91. Walsh CJ. The role of actin, actomyosin and microtubules in defining cell shape during the differentiation of Naegleria amebae into flagellates. Eur J Cell Biol 2007; 86(2): 85-98

92. Sohn HJ, Song KJ, Kang H, Ham AJ, Lee JH, Chwae YJ, Kim K, Park S, Kim JH, Shin HJ. Cellular characterization of actin gene concerned with contact-dependent mechanisms in Naegleria fowleri. Parasite Immunol 2019; 41(8): e12631

93. Dubray BL, Wilhelm WE, Jennings BR. Serology of Naegleria fowleri and Naegleria lovaniensis in a hospital survey. J Protozool 1987; 34(3): 322-327

94. Cerva L. Acanthamoeba culbertsoni and Naegleria fowleri: occurrence of antibodies in man. J Hyg Epidemiol Microbiol Immunol 1989; 33(1): 99-103

95. Lee J, Kang JM, Kim TI, Kim JH, Sohn HJ, Na BK, Shin HJ. Excretory and secretory proteins of Naegleria fowleri induce inflammatory responses in BV-2 microglial cells. J Eukaryot Microbiol 2017; 64(2): 183-192

96. Cervantes-Sandoval I, Serrano-Luna JJ, Meza-Cervantez P, Arroyo R, Tsutsumi V, Shibayama M. Naegleria fowleri induces MUC5AC and pro-inflammatory cytokines in human epithelial cells via ROS production and EGFR activation. Microbiology (Reading) 2009; 155(11): 3739-3747

97. Martínez-Castillo M, Santos-Argumedo L, Galván-Moroyoqui JM, Serrano-Luna J, Shibayama M. Toll-like receptors participate in Naegleria fowleri recognition. Parasitol Res 2018; 117(1): 75-87

98. Ferrante A, Mocatta TJ. Human neutrophils require activation by mononuclear leucocyte conditioned medium to kill the pathogenic free-living amoeba, Naegleria fowleri. Clin Exp Immunol 1984; 56(3): 559-566

99. Ferrante A, Thong YH. Unique phagocytic process in neutrophilmediated killing of Naeglaria fowleri. Immunol Lett 1980; 2(1): $37-41$

100. Holbrook TW, Boackle RJ, Parker BW, Vesely J. Activation of the alternative complement pathway by Naegleria fowleri. Infect Immun 1980; 30(1): 58-61

101. Michelson MK, Henderson WR Jr, Chi EY, Fritsche TR, Klebanoff SJ. Ultrastructural studies on the effect of tumor necrosis factor on the interaction of neutrophils and Naegleria fowleri. Am J Trop Med Hyg 1990; 42(3): 225-233

102. Papayannopoulos V, Metzler KD, Hakkim A, Zychlinsky A. Neutrophil elastase and myeloperoxidase regulate the formation of neutrophil extracellular traps. J Cell Biol 2010; 191(3): 677-691

103. Vyas IK, Jamerson M, Cabral GA, Marciano-Cabral F. Identification of peptidases in highly pathogenic vs. weakly pathogenic Naegleria fowleri amebae. J Eukaryot Microbiol 2015; 62(1): 5159

104. Kim JH, Song AR, Sohn HJ, Lee J, Yoo JK, Kwon D, Shin HJ. IL$1 \beta$ and IL-6 activate inflammatory responses of astrocytes against Naegleria fowleri infection via the modulation of MAPKs and AP1. Parasite Immunol 2013; 35(3-4): 120-128
105. Thong YH, Ferrante A, Shepherd C, Rowan-Kelly B. Resistance of mice to Naegleria meningoencephalitis transferred by immune serum. Trans R Soc Trop Med Hyg 1978; 72(6): 650-652

106. Reilly MF, White KL Jr, Bradley SG. Host resistance of mice to Naegleria fowleri infections. Infect Immun 1983; 42(2): 645-652

107. Reilly MF, Marciano-Cabral F, Bradley DW, Bradley SG. Agglutination of Naegleria fowleri and Naegleria gruberi by antibodies in human serum. J Clin Microbiol 1983; 17(4): 576-581

108. Jarillo-Luna A, Moreno-Fierros L, Campos-Rodríguez R, Rodríguez-Monroy MA, Lara-Padilla E, Rojas-Hernández S. Intranasal immunization with Naegleria fowleri lysates and Cry1 Ac induces metaplasia in the olfactory epithelium and increases IgA secretion. Parasite Immunol 2008; 30(1): 31-38

109. Carrasco-Yepez M, Rojas-Hernandez S, Rodriguez-Monroy MA, Terrazas LI, Moreno-Fierros L. Protection against Naegleria fowleri infection in mice immunized with Cry1Ac plus amoebic lysates is dependent on the STAT6 Th2 response. Parasite Immunol 2010; 32(9-10): 664-670

110. Carrasco-Yepez M, Campos-Rodriguez R, Lopez-Reyes I, BonillaLemus P, Rodriguez-Cortes AY, Contis-Montes de Oca A, JarilloLuna A, Miliar-Garcia A, Rojas-Hernandez S. Intranasal coadministration of Cholera toxin with amoeba lysates modulates the secretion of $\operatorname{IgA}$ and $\operatorname{IgG}$ antibodies, production of cytokines and expression of $\mathrm{pIgR}$ in the nasal cavity of mice in the model of Naegleria fowleri meningoencephalitis. Exp Parasitol 2014; 145(Suppl): S84-S92

111. Ryu JS, Im KI. The production and characterization of antiNaegleria fowleri monoclonal antibodies. Korean J Parasitol 1992; 30(1): 33-41

112. Shibayama M, Serrano-Luna JJ, Rojas-Hernández S, CamposRodríguez R, Tsutsumi V. Interaction of secretory immunoglobulin A antibodies with Naegleria fowleri trophozoites and collagen type I. Can J Microbiol 2003; 49(3): 164-170

113. Contis-Montes de Oca A, Carrasco-Yépez M, Campos-Rodríguez R, Pacheco-Yépez J, Bonilla-Lemus P, Pérez-López J, RojasHernández S. Neutrophils extracellular traps damage Naegleria fowleri trophozoites opsonized with human IgG. Parasite Immunol 2016; 38(8): 481-495

114. Carrasco-Yepez MM, Campos-Rodríguez R, Reséndiz-Albor AA, Peña-Juárez C, Contis-Montes de Oca A, Arciniega-Martínez IM, Bonilla-Lemus P, Rojas-Hernandez S. Naegleria fowleri immunization modifies lymphocytes and APC of nasal mucosa. Parasite Immunol 2018; 40(3): e12508

115. Cursons RT, Brown TJ, Keys EA, Moriarty KM, Till D. Immunity to pathogenic free-living amoebae: role of cell-mediated immunity. Infect Immun 1980; 29(2): 408-410

116. Toney DM, Marciano-Cabral F. Alterations in protein expression and complement resistance of pathogenic Naegleria amoebae. Infect Immun 1992; 60(7): 2784-2790

117. Toney DM, Marciano-Cabral F. Modulation of complement resistance and virulence of Naegleria fowleri amoebae by alterations in growth media. J Eukaryot Microbiol 1994; 41(4): 337-343

118. John DT. Primary amebic meningoencephalitis and the biology of Naegleria fowleri. Annu Rev Microbiol 1982; 36(1): 101-123

119. Rivera-Aguilar V, Hernández-Martínez D, Rojas-Hernández S, Oliver-Aguillón G, Tsutsumi V, Herrera-González N, Campos- 
Rodríguez R. Immunoblot analysis of IgA antibodies to Naegleria fowleri in human saliva and serum. Parasitol Res 2000; 86(9): 775780

120. Baig AM. Pathogenesis of amoebic encephalitis: are the amoebae being credited to an 'inside job' done by the host immune response? Acta Trop 2015; 148: 72-76

121. Thái TL, Kang JM, Lê HG, Lee J, Yoo WG, Shin HJ, Sohn WM, $\mathrm{Na}$ BK. Fowlerstefin, a cysteine protease inhibitor of Naegleria fowleri, induces inflammatory responses in BV-2 microglial cells in vitro. Parasit Vectors 2020; 13(1): 41

122. Movahedi Z, Shokrollahi MR, Aghaali M, Heydari H. Primary amoebic meningoencephalitis in an Iranian infant. Case Rep Med 2012; 2012: 782854

123. Mittal N, Mahajan L, Hussain Z, Gupta P, Khurana S. Primary amoebic meningoencephalitis in an infant. Indian J Med Microbiol 2019; 37(1): 120-122

124. Schuster FL, Visvesvara GS. Free-living amoebae as opportunistic and non-opportunistic pathogens of humans and animals. Int $\mathbf{J}$ Parasitol 2004; 34(9): 1001-1027

125. Zhang LL, Wu M, Hu BC, Chen HL, Pan JR, Ruan W, Yao LN. Identification and molecular typing of Naegleria fowleri from a patient with primary amebic meningoencephalitis in China. Int $\mathbf{J}$ Infect Dis 2018; 72: 28-33

126. Harris GR, Batra R. Naegleria fowleri. N Engl J Med 2020; 383(11): 1057

127. Chen M, Ruan W, Zhang L, Hu B, Yang X. Primary amebic meningoencephalitis: a case report. Korean J Parasitol 2019; 57(3): 291-294

128. Capewell LG, Harris AM, Yoder JS, Cope JR, Eddy BA, Roy SL, Visvesvara GS, Fox LM, Beach MJ. Diagnosis, clinical course, and treatment of primary amoebic meningoencephalitis in the United States, 1937-2013. J Pediatric Infect Dis Soc 2015; 4(4): e68-e75

129. Ong TYY, Khan NA, Siddiqui R. Brain-eating amoebae: predilection sites in the brain and disease outcome. J Clin Microbiol 2017; 55(7): 1989-1997

130. Lopez-Corella E, De Leon B, de Jonckheere JF. Primary amebic meningoencephalitis caused by Naegleria fowleri in an adolescent from Huetamo, Michoacan, Mexico. Bol Méd Hosp Infant México 1989; 46(9): 619-622

131. Barnett ND, Kaplan AM, Hopkin RJ, Saubolle MA, Rudinsky MF. Primary amoebic meningoencephalitis with Naegleria fowleri: clinical review. Pediatr Neurol 1996; 15(3): 230-234

132. Carter RF. Primary amoebic meningo-encephalitis. An appraisal of present knowledge. Trans R Soc Trop Med Hyg 1972; 66(2): 193208

133. Martinez AJ. Free-living amebas: natural history, prevention, diagnosis, pathology and treatment of disease. CRC Press, 1985

134. Sugita Y, Fujii T, Hayashi I, Aoki T, Yokoyama T, Morimatsu M, Fukuma T, Takamiya Y. Primary amebic meningoencephalitis due to Naegleria fowleri: an autopsy case in Japan. Pathol Int 1999; 49(5): 468-470

135. Visvesvara GS. Infections with free-living amebae. Handb Clin Neurol 2013; 114: 153-168

136. Hara T, Yagita K, Sugita Y. Pathogenic free-living amoebic encephalitis in Japan. Neuropathology 2019; 39(4): 251-258

137. Lam AH, de Silva M, Procopis P, Kan A. Primary amoebic (Naegleria) meningoencephalitis. J Comput Assist Tomogr 1982;
6(3): $620-623$

138. Kidney DD, Kim SH. CNS infections with free-living amebas: neuroimaging findings. AJR Am J Roentgenol 1998; 171(3): 809812

139. da Rocha-Azevedo B, Tanowitz HB, Marciano-Cabral F. Diagnosis of infections caused by pathogenic free-living amoebae. Interdiscip Perspect Infect Dis 2009; 2009: 251406

140. Hebbar S, Bairy I, Bhaskaranand N, Upadhyaya S, Sarma MS, Shetty AK. Fatal case of Naegleria fowleri meningo-encephalitis in an infant: case report. Ann Trop Paediatr 2005; 25(3): 223-226

141. Centers for Disease Control and Prevention. Update on emerging infections: news from the Centers for Disease Control and Prevention. Primary amebic meningoencephalitis-Arizona, Florida, and Texas, 2007. Ann Emerg Med 2009; 54(3): 469-471

142. Martinez AJ, Visvesvara GS. Laboratory diagnosis of pathogenic free-living amoebas: Naegleria, Acanthamoeba, and Leptomyxid. Clin Lab Med 1991; 11(4): 861-872

143. Pugh JJ, Levy RA. Naegleria fowleri: diagnosis, pathophysiology of brain inflammation, and antimicrobial treatments. ACS Chem Neurosci 2016; 7(9): 1178-1179

144. Centers for Disease Control and Prevention (CDC). Investigational drug available directly from CDC for the treatment of infections with free-living amebae. MMWR Morb Mortal Wkly Rep 2013; 62(33): 666

145. Visvesvara GS. Free-living amebae as opportunistic agents of human disease. J Neuroparasitology 2010; 1: 41-53

146. Visvesvara GS, Peralta MJ, Brandt FH, Wilson M, Aloisio C, Franko E. Production of monoclonal antibodies to Naegleria fowleri, agent of primary amebic meningoencephalitis. J Clin Microbiol 1987; 25(9): 1629-1634

147. Behets J, Seghi F, Declerck P, Verelst L, Duvivier L, Van Damme A, Ollevier F. Detection of Naegleria spp. and Naegleria fowleri: a comparison of flagellation tests, ELISA and PCR. Water Sci Technol 2003; 47(3): 117-122

148. Reveiller FL, Varenne MP, Pougnard C, Cabanes PA, Pringuez E, Pourima B, Legastelois S, Pernin P. An enzyme-linked immunosorbent assay (ELISA) for the identification of Naegleria fowleri in environmental water samples. J Eukaryot Microbiol 2003; 50(2): 109-113

149. Lares-Jiménez LF, Borquez-Román MA, Alfaro-Sifuentes R, Meza-Montenegro MM, Casillas-Hernández R, Lares-Villa F. Detection of serum antibodies in children and adolescents against Balamuthia mandrillaris, Naegleria fowleri and Acanthamoeba T4. Exp Parasitol 2018; 189: 28-33

150. Réveiller FL, Cabanes PA, Marciano-Cabral F. Development of a nested PCR assay to detect the pathogenic free-living amoeba Naegleria fowleri. Parasitol Res 2002; 88(5): 443-450

151. Qvarnstrom Y, Visvesvara GS, Sriram R, da Silva AJ. Multiplex real-time PCR assay for simultaneous detection of Acanthamoeba spp., Balamuthia mandrillaris, and Naegleria fowleri. J Clin Microbiol 2006; 44(10): 3589-3595

152. Hikal WM, Dkhil MA. Nested PCR assay for the rapid detection of Naegleria fowleri from swimming pools in Egypt. Acta Ecol Sin 2018; 38(2): 102-107

153. Schild M, Gianinazzi C, Gottstein B, Müller N. PCR-based diagnosis of Naegleria sp. infection in formalin-fixed and paraffinembedded brain sections. J Clin Microbiol 2007; 45(2): 564-567 
154. Xue J, Caton K, Sherchan SP. Comparison of next-generation droplet digital PCR with quantitative PCR for enumeration of Naegleria fowleri in environmental water and clinical samples. Lett Appl Microbiol 2018; 67(4): 322-328

155. Panda A, Mirdha BR, Rastogi N, Kasuhik S. Understanding the true burden of "Naegleria fowleri" (Vahlkampfiidae) in patients from Northern states of India: source tracking and significance. Eur J Protistol 2020; 76: 125726

156. Griffin JL. Temperature tolerance of pathogenic and nonpathogenic free-living amoebas. Science 1972; 178(4063): 869-870

157. Gupta S, Das SR. Stock cultures of free-living amebas: effect of temperature on viability and pathogenicity. J Parasitol 1999; 85(1): 137-139

158. Diaz J. Seasonal primary amebic meningoencephalitis (PAM) in the south: summertime is PAM time. J La State Med Soc 2012; 164(3): 148-150, 152-155

159. Cooper AM, Aouthmany S, Shah K, Rega PP. Killer amoebas: primary amoebic meningoencephalitis in a changing climate. JAAPA 2019; 32(6): 30-35

160. Caruzo G, Cardozo J. Primary amoebic meningoencephalitis: a new case from Venezuela. Trop Doct 2008; 38(4): 256-257

161. Lawande RV, Abraham SN, John I, Egler LJ. Recovery of soil Amebas from the nasal passages of children during the dusty harmattan period in Zaria. Am J Clin Pathol 1979; 71(2): 201-203

162. Ugonabo JA, Gugnani HC. Nasal carriage of Naegleria fowleri and its environmental occurrence in Borno State, Nigeria. J Commun Dis 1989; 21(2): 111-113

163. Shenoy S, Wilson G, Prashanth HV, Vidyalakshmi K, Dhanashree B, Bharath R. Primary meningoencephalitis by Naegleria fowleri: first reported case from Mangalore, South India. J Clin Microbiol 2002; 40(1): 309-310

164. Grace E, Asbill S, Virga K. Naegleria fowleri: pathogenesis, diagnosis, and treatment options. Antimicrob Agents Chemother 2015; 59(11): 6677-6681

165. Goswick SM, Brenner GM. Activities of azithromycin and amphotericin B against Naegleria fowleri in vitro and in a mouse model of primary amebic meningoencephalitis. Antimicrob Agents Chemother 2003; 47(2): 524-528

166. Kim JH, Jung SY, Lee YJ, Song KJ, Kwon D, Kim K, Park S, Im $\mathrm{KI}$, Shin HJ. Effect of therapeutic chemical agents in vitro and on experimental meningoencephalitis due to Naegleria fowleri. Antimicrob Agents Chemother 2008; 52(11): 4010-4016

167. Rice CA, Colon BL, Alp M, Göker H, Boykin DW, Kyle DE. Bisbenzimidazole hits against Naegleria fowleri discovered with new high-throughput screens. Antimicrob Agents Chemother 2015; 59(4): 2037-2044

168. Debnath A, Calvet CM, Jennings G, Zhou W, Aksenov A, Luth MR, Abagyan R, Nes WD, McKerrow JH, Podust LM. CYP51 is an essential drug target for the treatment of primary amoebic meningoencephalitis (PAM). PLoS Negl Trop Dis 2017; 11(12): e0006104

169. Escrig JI, Hahn HJ, Debnath A. Activity of auranofin against multiple genotypes of Naegleria fowleri and its synergistic effect with amphotericin B in vitro. ACS Chem Neurosci 2020; 11(16): 2464-2471

170. De Jonckheere JF. Isoenzyme and total protein-analysis by agarose isoelectric-focusing, and taxonomy of the genus Acanthamoeba. J
Protozool 1983; 30(4): 701-706

171. Moura H, Wallace S, Visvesvara GS. Acanthamoeba healyi n. sp. and the isoenzyme and immunoblot profiles of Acanthamoeba spp., groups 1 and 3. J Protozool 1992; 39(5): 573-583

172. Walochnik J, Sommer K, Obwaller A, Haller-Schober EM, Aspöck H. Characterisation and differentiation of pathogenic and nonpathogenic Acanthamoeba strains by their protein and antigen profiles. Parasitol Res 2004; 92(4): 289-298

173. Fuerst PA, Booton GC. Species, sequence types and alleles: dissecting genetic variation in Acanthamoeba. Pathogens 2020; 9(7): E534

174. Walochnik J, Scheikl U, Haller-Schober EM. Twenty years of Acanthamoeba diagnostics in Austria. J Eukaryot Microbiol 2015; 62(1): 3-11

175. Behera HS, Satpathy G, Tripathi M. Isolation and genotyping of Acanthamoeba spp. from Acanthamoeba meningitis/meningoencephalitis (AME) patients in India. Parasit Vectors 2016; 9(1): 442

176. Khorsandi Rafsanjani M, Hajialilo E, Saraei M, Alizadeh SA, Javadi A. Isolation and molecular identification of Acanthamoeba and Naegleria from agricultural water canal in Qazvin, Iran. Iran J Parasitol 2020; 15(3): 393-402

177. Willaert E, Stevens AR, Tyndall RL. Acanthamoeba royreba sp. n. from a human tumor cell culture. J Protozool 1978; 25(1): 1-14

178. Daggett PM, Lipscomb D, Sawyer TK, Nerad TA. A molecular approach to the phylogeny of Acanthamoeba. Biosystems 1985; 18(3-4): 399-405

179. Gardner HA, Martinez AJ, Visvesvara GS, Sotrel A. Granulomatous amebic encephalitis in an AIDS patient. Neurology 1991; 41(12): 1993-1995

180. Di Gregorio C, Rivasi F, Mongiardo N, De Rienzo B, Wallace S, Visvesvara GS. Acanthamoeba meningoencephalitis in a patient with acquired immunodeficiency syndrome. Arch Pathol Lab Med 1992; 116(12): 1363-1365

181. Chung DI, Kong HH, Kim TH, Hwang MY, Yu HS, Yun HC, Seol SY. Bacterial endosymbiosis within the cytoplasm of Acanthamoeba lugdunensis isolated from a contact lens storage case. Korean J Parasitol 1997; 35(2): 127-133

182. Faude F, Sünnemann S, Retzlaff C, Meier T, Wiedemann P. Therapy refractory keratitis. Contact lens-induced keratitis caused by Acanthamoeba palestinensis. Ophthalmologe 1997; 94(6): 448-449

183. García MT, Jones S, Pelaz C, Millar RD, Abu Kwaik Y. Acanthamoeba polyphaga resuscitates viable non-culturable Legionella pneumophila after disinfection. Environ Microbiol 2007; 9(5): 1267-1277

184. Qvarnstrom Y, Nerad TA, Visvesvara GS. Characterization of a new pathogenic Acanthamoeba species, A. byersi n. sp., isolated from a human with fatal amoebic encephalitis. J Eukaryot Microbiol 2013; 60(6): 626-633

185. van Zyl LM, Andrew N, Chehade M, Sadlon TA, Badenoch PR. Acanthamoeba lenticulata keratitis in a hard contact lens wearer. Clin Exp Ophthalmol 2013; 41(8): 810-812

186. González-Robles A, Omaña-Molina M, Salazar-Villatoro L, Flores-Maldonado C, Lorenzo-Morales J, Reyes-Batlle M, Arnalich-Montiel F, Martínez-Palomo A. Acanthamoeba culbertsoni isolated from a clinical case with intraocular dissemination: structure and in vitro analysis of the interaction with hamster 
cornea and MDCK epithelial cell monolayers. Exp Parasitol 2017; 183: $245-253$

187. Wu D, Qiao K, Feng M, Fu Y, Cai J, Deng Y, Tachibana H, Cheng $\mathrm{X}$. Apoptosis of Acanthamoeba castellanii trophozoites induced by oleic acid. J Eukaryot Microbiol 2018; 65(2): 191-199

188. Ezz Eldin HM, Sarhan RM, Khayyal AE. The impact of vinegar on pathogenic Acanthamoeba astronyxis isolate. J Parasit Dis 2019; 43(3): 351-359

189. Singh A, Acharya M, Jose N, Gandhi A, Sharma S. 18S rDNA sequencing aided diagnosis of Acanthamoeba jacobsi keratitis - a case report. Indian J Ophthalmol 2019; 67(11): 1886-1888

190. Ávila-Blanco ME, Martín-Pérez T, Ventura-Juárez J, PérezSerrano J. Experimental keratitis in rats caused by Acanthamoeba griffini: a kinetic histopathological study. Parasite Immunol 2020; 42(3): e12692

191. Hasni I, Andréani J, Colson P, La Scola B. Description of virulent factors and horizontal gene transfers of keratitis-associated amoeba Acanthamoeba triangularis by genome analysis. Pathogens 2020; 9(3): E217

192. Roshni Prithiviraj S, Rajapandian SGK, Gnanam H, Gunasekaran R, Mariappan P, Sankalp Singh S, Prajna L. Clinical presentations, genotypic diversity and phylogenetic analysis of Acanthamoeba species causing keratitis. J Med Microbiol 2020; 69(1): 87-95

193. Anzil AP, Rao C, Wrzolek MA, Visvesvara GS, Sher JH, Kozlowski PB. Amebic meningoencephalitis in a patient with AIDS caused by a newly recognized opportunistic pathogen. Leptomyxid ameba. Arch Pathol Lab Med 1991; 115(1): 21-25

194. Gordon SM, Steinberg JP, DuPuis MH, Kozarsky PE, Nickerson JF, Visvesvara GS. Culture isolation of Acanthamoeba species and leptomyxid amebas from patients with amebic meningoencephalitis, including two patients with AIDS. Clin Infect Dis 1992; 15(6): 1024-1030

195. Griesemer DA, Barton LL, Reese CM, Johnson PC, Gabrielsen JA, Talwar D, Visvesvara GS. Amebic meningoencephalitis caused by Balamuthia mandrillaris. Pediatr Neurol 1994; 10(3): 249-254

196. Niyyati M, Lorenzo-Morales J, Rezaeian M, Martin-Navarro CM, Haghi AM, Maciver SK, Valladares B. Isolation of Balamuthia mandrillaris from urban dust, free of known infectious involvement. Parasitol Res 2009; 106(1): 279-281

197. Cabello-Vílchez AM, Reyes-Batlle M, Montalbán-Sandoval E, Martín-Navarro CM, López-Arencibia A, Elias-Letts R, Guerra H, Gotuzzo E, Martínez-Carretero E, Piñero JE, Maciver SK, Valladares B, Lorenzo-Morales J. The isolation of Balamuthia mandrillaris from environmental sources from Peru. Parasitol Res 2014; 113(7): 2509-2513

198. Latifi AR, Niyyati M, Lorenzo-Morales J, Haghighi A, Seyyed Tabaei SJ, Lasjerdi Z. Presence of Balamuthia mandrillaris in hot springs from Mazandaran province, northern Iran. Epidemiol Infect 2016; 144(11): 2456-2461

199. Visvesvara GS, Martinez AJ, Schuster FL, Leitch GJ, Wallace SV, Sawyer TK, Anderson M. Leptomyxid ameba, a new agent of amebic meningoencephalitis in humans and animals. J Clin Microbiol 1990; 28(12): 2750-2756

200. Kinde H, Visvesvara GS, Barr BC, Nordhausen RW, Chiu PHW. Amebic meningoencephalitis caused by Balamuthia mandrillaris (leptomyxid ameba) in a horse. J Vet Diagn Invest 1998; 10(4): 378-381
201. Finnin PJ, Visvesvara GS, Campbell BE, Fry DR, Gasser RB. Multifocal Balamuthia mandrillaris infection in a dog in Australia. Parasitol Res 2007; 100(2): 423-426

202. Hodge PJ, Kelers K, Gasser RB, Visvesvara GS, Martig S, Long $\mathrm{SN}$. Another case of canine amoebic meningoencephalitis - the challenges of reaching a rapid diagnosis. Parasitol Res 2011; 108(4): 1069-1073

203. Booton GC, Carmichael JR, Visvesvara GS, Byers TJ, Fuerst PA. Genotyping of Balamuthia mandrillaris based on nuclear 18S and mitochondrial 16S rRNA genes. Am J Trop Med Hyg 2003; 68(1): 65-69

204. Lares-Jiménez LF, Booton GC, Lares-Villa F, Velázquez-Contreras CA, Fuerst PA. Genetic analysis among environmental strains of Balamuthia mandrillaris recovered from an artificial lagoon and from soil in Sonora, Mexico. Exp Parasitol 2014; 145 (Suppl): S57-S61

205. Kucerova Z, Sriram R, Wilkins PP, Visvesvara GS. Identification of antigenic targets for immunodetection of Balamuthia mandrillaris infection. Clin Vaccine Immunol 2011; 18(8): 1297-1301

206. Martínez AJ. Is Acanthamoeba encephalitis an opportunistic infection? Neurology 1980; 30(6): 567-574

207. Lackner P, Beer R, Broessner G, Helbok R, Pfausler B, Brenneis C, Auer H, Walochnik J, Schmutzhard E. Acute granulomatous acanthamoeba encephalitis in an immunocompetent patient. Neurocrit Care 2010; 12(1): 91-94

208. Cope JR, Landa J, Nethercut H, Collier SA, Glaser C, Moser M, Puttagunta R, Yoder JS, Ali IK, Roy SL. The epidemiology and clinical features of Balamuthia mandrillaris disease in the United States, 1974-2016. Clin Infect Dis 2019; 68(11): 1815-1822

209. Wu X, Yan G, Han S, Ye Y, Cheng X, Gong H, Yu H. Diagnosing Balamuthia mandrillaris encephalitis via next-generation sequencing in a 13-year-old girl. Emerg Microbes Infect 2020; 9(1): 1379-1387

210. Kiderlen AF, Laube U, Radam E, Tata PS. Oral infection of immunocompetent and immunodeficient mice with Balamuthia mandrillaris amebae. Parasitol Res 2007; 100(4): 775-782

211. Yera H, Dupouy-Camet J, Jackson JW, Sriram R, Sweat S, Goldstein JM, Visvesvara GS. In vitro growth, cytopathic effects and clearance of monolayers by clinical isolates of Balamuthia mandrillaris in human skin cell cultures. Exp Parasitol 2015; 156: 61-67

212. Gupte AA, Hocevar SN, Lea AS, Kulkarni RD, Schain DC, Casey MJ, Zendejas-Ruiz IR, Chung WK, Mbaeyi C, Roy SL, Visvesvara GS, da Silva AJ, Tallaj J, Eckhoff D, Baddley JW. Transmission of Balamuthia mandrillaris through solid organ transplantation: utility of organ recipient serology to guide clinical management. Am J Transplant 2014; 14(6): 1417-1424

213. Farnon EC, Kokko KE, Budge PJ, Mbaeyi C, Lutterloh EC, Qvarnstrom Y, da Silva AJ, Shieh WJ, Roy SL, Paddock CD, Sriram R, Zaki SR, Visvesvara GS, Kuehnert MJ, Balamuthia Transplant Investigation Teams; Weiss J, Komatsu K, Manch R, Ramos A, Echeverria L, Moore A, Zakowski P, Kittleson M, Kobashigawa J, Yoder J, Beach M, Mahle W, Kanter K, Geraghty PJ, Navarro E, Hahn C, Fujita S, Stinson J, Trachtenberg J, Byers P, Cheung M, Jie T, Kaplan B, Gruessner R, Bracamonte E, Viscusi C, Gonzalez-Peralta R, Lawrence R, Fratkin J, Butt F. Transmission of Balamuthia mandrillaris by organ transplantation. 
Clin Infect Dis 2016; 63(7): 878-888

214. Kot K, Łanocha-Arendarczyk NA, Kosik-Bogacka DI. Amoebas from the genus Acanthamoeba and their pathogenic properties. Ann Parasitol 2018; 64(4): 299-308

215. Martínez AJ, Schuster FL, Visvesvara GS. Balamuthia mandrillaris: its pathogenic potential. J Eukaryot Microbiol 2001; 48 (Suppl): 6S-9S

216. Kiderlen AF, Laube U. Balamuthia mandrillaris, an opportunistic agent of granulomatous amebic encephalitis, infects the brain via the olfactory nerve pathway. Parasitol Res 2004; 94(1): 49-52

217. Matin A, Siddiqui R, Jayasekera S, Khan NA. Increasing importance of Balamuthia mandrillaris. Clin Microbiol Rev 2008; 21(3): 435-448

218. Nielsen SE, Ivarsen A, Hjortdal J. Increasing incidence of Acanthamoeba keratitis in a large tertiary ophthalmology department from year 1994 to 2018. Acta Ophthalmol 2020; 98(5): 445448 ;

219. Garajová M, Mrva M. Amoebae of the genus Acanthamoe$b a$ - causative agents of human infections. Epidemiol Mikrobiol Imunol 2011; 60(3): 121-130

220. Visvesvara GS. Amebic meningoencephalitides and keratitis: challenges in diagnosis and treatment. Curr Opin Infect Dis 2010; 23(6): 590-594

221. Betanzos A, Bañuelos C, Orozco E. Host invasion by pathogenic amoebae: epithelial disruption by parasite proteins. Genes (Basel) 2019; 10(8): E618

222. Khan NA. Acanthamoeba: biology and increasing importance in human health. FEMS Microbiol Rev 2006; 30(4): 564-595

223. Serrano-Luna JJ, Cervantes-Sandoval I, Calderón J, NavarroGarcía F, Tsutsumi V, Shibayama M. Protease activities of Acanthamoeba polyphaga and Acanthamoeba castellanii. Can J Microbiol 2006; 52(1): 16-23

224. Soto-Arredondo KJ, Flores-Villavicencio LL, Serrano-Luna JJ, Shibayama M, Sabanero-López M. Biochemical and cellular mechanisms regulating Acanthamoeba castellanii adherence to host cells. Parasitology 2014; 141(4): 531-541

225. Castelan-Ramírez I, Salazar-Villatoro L, Chávez-Munguía B, Salinas-Lara C, Sánchez-Garibay C, Flores-Maldonado C, Hernández-Martínez D, Anaya-Martínez V, Ávila-Costa MR, Méndez-Cruz AR, Omaña-Molina M. Schwann cell autophagy and necrosis as mechanisms of cell death by Acanthamoeba. Pathogens 2020; 9(6): E458

226. Cole TB, John DT. Effects of cytochalasin B on Naegleria fowleri amoebostomes. Proceedings, Annual Meeting, Electron Microscopy Society of America 1985; 43: 482-483

227. González-Robles A, González-Lázaro M, Omaña-Molina M, Martínez-Palomo A. Acanthamoeba castellanii: endocytic structures involved in the ingestion of diverse target elements. Acta Protozool 2009; 48(4): 329-334

228. Piña-Vázquez C, Reyes-López M, Ortíz-Estrada G, de la Garza M, Serrano-Luna J. Host-parasite interaction: parasite-derived andinduced proteases that degrade human extracellular matrix. J Parasitol Res 2012; 2012: 748206

229. Khan NA. Acanthamoeba and the blood-brain barrier: the breakthrough. J Med Microbiol 2008; 57(9): 1051-1057

230. Khan NA, Siddiqui R. Acanthamoeba affects the integrity of human brain microvascular endothelial cells and degrades the tight junction proteins. Int J Parasitol 2009; 39(14): 1611-1616

231. Coronado-Velázquez D, Betanzos A, Serrano-Luna J, Shibayama $\mathrm{M}$. An in vitro model of the blood-brain barrier: Naegleria fowleri affects the tight junction proteins and activates the microvascular endothelial cells. J Eukaryot Microbiol 2018; 65(6): 804-819

232. Siddiqui R, Emes R, Elsheikha H, Khan NA. Area 51: How do Acanthamoeba invade the central nervous system? Trends Parasitol 2011; 27(5): 185-189

233. Chusattayanond AD, Boonsilp S, Kasisit J, Boonmee A, Warit S. Thai Acanthamoeba isolate (T4) induced apoptotic death in neuroblastoma cells via the Bax-mediated pathway. Parasitol Int 2010; 59(4): 512-516

234. Huang JM, Chang YT, Lin WC. The biochemical and functional characterization of M28 aminopeptidase protein secreted by Acanthamoeba spp. on host cell interaction. Molecules 2019; 24(24): E4573

235. Sissons J, Alsam S, Goldsworthy G, Lightfoot M, Jarroll EL, Khan NA. Identification and properties of proteases from an Acanthamoeba isolate capable of producing granulomatous encephalitis. BMC Microbiol 2006; 6(1): 42

236. Matin A, Siddiqui R, Jung SY, Kim KS, Stins M, Khan NA. Balamuthia mandrillaris interactions with human brain microvascular endothelial cells in vitro. J Med Microbiol 2007; 56(8): $1110-1115$

237. Siddiqui R, Khan NA. Balamuthia amoebic encephalitis: an emerging disease with fatal consequences. Microb Pathog 2008; 44(2): 89-97

238. Matin A, Jeong SR, Stins M, Khan NA. Effects of human serum on Balamuthia mandrillaris interactions with human brain microvascular endothelial cells. J Med Microbiol 2007; 56(1): 30-35

239. Siddiqui R, Khan NA. Balamuthia mandrillaris: morphology, biology, and virulence. Trop Parasitol 2015; 5(1): 15-22

240. Jayasekera S, Matin A, Sissons J, Maghsood AH, Khan NA. Balamuthia mandrillaris stimulates interleukin-6 release in primary human brain microvascular endothelial cells via a phosphatidylinositol 3-kinase-dependent pathway. Microbes Infect 2005; 7(13): 1345-1351

241. Rocha-Azevedo B, Jamerson M, Cabral GA, Silva-Filho FC, Marciano-Cabral F. The interaction between the amoeba Balamuthia mandrillaris and extracellular matrix glycoproteins in vitro. Parasitology 2007; 134(1): 51-58

242. Matin A, Stins M, Kim KS, Khan NA. Balamuthia mandrillaris exhibits metalloprotease activities. FEMS Immunol Med Microbiol 2006; 47(1): 83-91

243. Matin A, Khan NA. Demonstration and partial characterization of ecto-ATPase in Balamuthia mandrillaris and its possible role in the host-cell interactions. Lett Appl Microbiol 2008; 47(4): 348-354

244. Lorenzo-Morales J, Khan NA, Walochnik J. An update on Acanthamoeba keratitis: diagnosis, pathogenesis and treatment. Parasite 2015; 22: 10

245. Değerli S, Değerli N, Çamur D, Doğan Ö, İlter H. Genotyping by sequencing of Acanthamoeba and Naegleria isolates from the thermal pool distributed throughout Turkey. Acta Parasitol 2020; 65(1): 174-186

246. Cursons RT, Brown TJ, Keys EA, Moriarty KM, Till D. Immunity to pathogenic free-living amoebae: role of humoral antibody. Infect Immun 1980; 29(2): 401-407 
247. Wojtkowiak-Giera A, Derda M, Kolasa-Wołosiuk A, Hadaś E, Kosik-Bogacka D, Solarczyk P, Jagodziński PP, WandurskaNowak E. Toll-like receptors in the brain of mice following infection with Acanthamoeba spp. Parasitol Res 2016; 115(11): 4335-4344

248. Derda M, Wojtkowiak-Giera A, Kolasa-Wołosiuk A, KosikBogacka D, Hadaś E, Jagodziński PP, Wandurska-Nowak E. Acanthamoeba infection in lungs of mice expressed by toll-like receptors (TLR2 and TLR4). Exp Parasitol 2016; 165: 30-34

249. Pumidonming W, Walochnik J, Dauber E, Petry F. Binding to complement factors and activation of the alternative pathway by Acanthamoeba. Immunobiology 2011; 216(1-2): 225-233

250. Ferrante A, Rowan-Kelly B. Activation of the alternative pathway of complement by Acanthamoeba culbertsoni. Clin Exp Immunol 1983; 54(2): 477-485

251. Stewart GL, Shupe K, Kim I, Silvany RE, Alizadeh H, McCulley JP, Niederkorn JY. Antibody-dependent neutrophil-mediated killing of Acanthamoeba castellanii. Int J Parasitol 1994; 24(5): 739742

252. Marciano-Cabral F, Toney DM. The interaction of Acanthamoeba spp. with activated macrophages and with macrophage cell lines. J Eukaryot Microbiol 1998; 45(4): 452-458

253. Benedetto N, Rossano F, Gorga F, Folgore A, Rao M, Romano Carratelli C. Defense mechanisms of IFN- $\gamma$ and LPS-primed murine microglia against Acanthamoeba castellanii infection. Int Immunopharmacol 2003; 3(6): 825-834

254. Mattana A, Sanna M, Cano A, Delogu G, Erre G, Roberts CW, Henriquez FL, Fiori PL, Cappuccinelli P. Acanthamoeba castellanii genotype $\mathrm{T} 4$ stimulates the production of interleukin-10 as well as proinflammatory cytokines in THP-1 cells, human peripheral blood mononuclear cells, and human monocyte-derived macrophages. Infect Immun 2016; 84(10): 2953-2962

255. Cano A, Mattana A, Woods S, Henriquez FL, Alexander J, Roberts CW. Acanthamoeba activates macrophages predominantly through Toll-like receptor 4- and MyD88-dependent mechanisms to induce interleukin-12 (IL-12) and IL-6. Infect Immun 2017; 85 (6): e01054-16

256. Kim KH, Shin CO, Im K. Natural killer cell activity in mice infected with free-living amoeba with reference to their pathogenicity. Korean J Parasitol 1993; 31(3): 239-248

257. Kim JY, Na BK, Song KJ, Park MH, Park YK, Kim TS. Functional expression and characterization of an iron-containing superoxide dismutase of Acanthamoeba castellanii. Parasitol Res 2012; 111(4): 1673-1682

258. Huang ZH, Ferrante A, Carter RF. Serum antibodies to Balamuthia mandrillaris, a free-living amoeba recently demonstrated to cause granulomatous amoebic encephalitis. J Infect Dis 1999; 179(5): 1305-1308

259. Schuster FL, Honarmand S, Visvesvara GS, Glaser CA. Detection of antibodies against free-living amoebae Balamuthia mandrillaris and Acanthamoeba species in a population of patients with encephalitis. Clin Infect Dis 2006; 42(9): 1260-1265

260. Toney DM, Marciano-Cabral F. Resistance of Acanthamoeba species to complement lysis. J Parasitol 1998; 84(2): 338-344

261. Jayasekera S, Sissons J, Tucker J, Rogers C, Nolder D, Warhurst D, Alsam S, White JML, Higgins EM, Khan NA. Post-mortem culture of Balamuthia mandrillaris from the brain and cerebrospinal fluid of a case of granulomatous amoebic meningoencephalitis, using human brain microvascular endothelial cells. J Med Microbiol 2004; 53(10): 1007-1012

262. Matin A, Nawaz S, Jung SY. Report: Effect of macrophage alone or primed with cytokines on Balamuthia mandrillaris interactions with human brain microvascular endothelial cells in vitro. Pak J Pharm Sci 2018; 31(6): 2553-2559

263. Guzmán-Téllez P, Martínez-Castillo M, Flores-Huerta N, RosalesMorgan G, Pacheco-Yépez J, la Garza M, Serrano-Luna J, Shibayama M. Lectins as virulence factors in Entamoeba histolytica and free-living amoebae. Future Microbiol 2020; 15(10): 919-936

264. Robbins SL, Kumar V, Cotran RS. Robbins and Cotran Pathologic Basis of Disease. 8th ed. Philadelphia, PA: Saunders/Elsevier, 2010

265. Baig AM. Granulomatous amoebic encephalitis: ghost response of an immunocompromised host? J Med Microbiol 2014; 63(Pt 12): 1763-1766

266. Lee DC, Fiester SE, Madeline LA, Fulcher JW, Ward ME, Schammel CM, Hakimi RK. Acanthamoeba spp. and Balamuthia mandrillaris leading to fatal granulomatous amebic encephalitis. Forensic Sci Med Pathol 2020; 16(1): 171-176

267. Vernon SE, Acar BC, Pham SM, Fertel D. Acanthamoeba infection in lung transplantation: report of a case and review of the literature. Transpl Infect Dis 2005; 7(3-4): 154-157

268. Duarte AG, Sattar F, Granwehr B, Aronson JF, Wang Z, Lick S. Disseminated acanthamoebiasis after lung transplantation. J Heart Lung Transplant 2006; 25(2): 237-240

269. Schimmel M, Mehta I. Granulomatous amebic encephalitis. N Engl J Med 2020; 383(13): 1262

270. Reddy R, Vijayasaradhi M, Uppin MS, Challa S, Jabeen A, Borghain R. Acanthamoeba meningoencephalitis in an immunocompetent patient: an autopsy case report. Neuropathology 2011; 31(2): 183-187

271. Sütçü M, Aktürk H, Gülümser-Şişko S, Acar M, Erol OB, Somer A, Bilgiç B, Salman N. Granulomatous amebic encephalitis caused by Acanthamoeba in an immuncompetent child. Turk J Pediatr 2018; 60(3): 340-343

272. Shehab KW, Aboul-Nasr K, Elliott SP. Balamuthia mandrillaris granulomatous amebic encephalitis with renal dissemination in a previously healthy child: case report and review of the pediatric literature. J Pediatric Infect Dis Soc 2018; 7(3): e163-e168

273. Wang L, Cheng W, Li B, Jian Z, Qi X, Sun D, Gao J, Lu X, Yang Y, Lin K, Lu C, Chen J, Li C, Wang G, Gao T. Balamuthia mandrillaris infection in China: a retrospective report of 28 cases. Emerg Microbes Infect 2020; 9(1): 2348-2357

274. Yang Y, Hu X, Min L, Dong X, Guan Y. Balamuthia mandrillarisrelated primary amoebic encephalitis in China diagnosed by next generation sequencing and a review of the literature. Lab Med 2020; 51(2): e20-e26

275. Bravo FG, Alvarez PJ, Gotuzzo E. Balamuthia mandrillaris infection of the skin and central nervous system: an emerging disease of concern to many specialties in medicine. Curr Opin Infect Dis 2011; 24(2): 112-117

276. Bravo FG, Seas C. Balamuthia mandrillaris amoebic encephalitis: an emerging parasitic infection. Curr Infect Dis Rep 2012; 14(4): 391-396

277. Martinez AJ, Janitschke K. Acanthamoeba, an opportunistic 
microorganism: a review. Infection 1985; 13(6): 251-256

278. Coven SL, Song E, Steward S, Pierson CR, Cope JR, Ali IK, Ardura MI, Hall MW, Chung MG, Bajwa RPS. Acanthamoeba granulomatous amoebic encephalitis after pediatric hematopoietic stem cell transplant. Pediatr Transplant 2017; 21(8): e13060

279. Ghadage DP, Choure AC, Wankhade AB, Bhore AV. Opportunistic free: living amoeba now becoming a usual pathogen? Indian J Pathol Microbiol 2017; 60(4): 601-603

280. The Editors. Balamuthia mandrillaris infection. J Med Microbiol 2001; 50(3): 205-207

281. Schuster FL, Visvesvara GS. Opportunistic amoebae: challenges in prophylaxis and treatment. Drug Resist Updat 2004; 7(1): 41-51

282. Pan D, Bridges LR, du Parcq J, Mahadeva U, Roy S, Ali IKM, Cosgrove CA, Chiodini PL, Zhang L. A rare cause of left-sided weakness in an elderly woman: amoebic encephalitis. Lancet 2020; 396(10244): e1

283. Bravo FG. Cutaneous manifestations of infection by free-living amebas. In: Tyring SK. Tropical Dermatology. Philadelphia: Churchill Livingstone, 2006: 49-55

284. Kalra SK, Sharma P, Shyam K, Tejan N, Ghoshal U. Acanthamoeba and its pathogenic role in granulomatous amebic encephalitis. Exp Parasitol 2020; 208: 107788

285. Bakardjiev A, Azimi PH, Ashouri N, Ascher DP, Janner D, Schuster FL, Visvesvara GS, Glaser C. Amebic encephalitis caused by Balamuthia mandrillaris: report of four cases. Pediatr Infect Dis J 2003; 22(5): 447-452

286. Seijo Martinez M, Gonzalez-Mediero G, Santiago P, Rodriguez De Lope A, Diz J, Conde C, Visvesvara GS. Granulomatous amebic encephalitis in a patient with AIDS: isolation of acanthamoeba sp. Group II from brain tissue and successful treatment with sulfadiazine and fluconazole. J Clin Microbiol 2000; 38(10): 3892-3895

287. Thamtam VK, Uppin MS, Pyal A, Kaul S, Rani JY, Sundaram C. Fatal granulomatous amoebic encephalitis caused by Acanthamoeba in a newly diagnosed patient with systemic lupus erythematosus. Neurol India 2016; 64(1): 101-104

288. Slater CA, Sickel JZ, Visvesvara GS, Pabico RC, Gaspari AA. Brief report: successful treatment of disseminated Acanthamoeba infection in an immunocompromised patient. N Engl J Med 1994; 331(2): $85-87$

289. Walia R, Montoya JG, Visvesvera GS, Booton GC, Doyle RL. A case of successful treatment of cutaneous Acanthamoeba infection in a lung transplant recipient. Transpl Infect Dis 2007; 9(1): 51-54

290. Lorenzo-Morales J, Cabello-Vílchez AM, Martín-Navarro CM, Martínez-Carretero E, Piñero JE, Valladares B. Is Balamuthia mandrillaris a public health concern worldwide? Trends Parasitol 2013; 29(10): 483-488

291. Sell JJ, Rupp FW, Orrison WW Jr. Granulomatous amebic encephalitis caused by acanthamoeba. Neuroradiology 1997; 39(6): 434-436

292. Shirwadkar CG, Samant R, Sankhe M, Deshpande R, Yagi S, Schuster FL, Sriram R, Visvesvara GS. Acanthamoeba encephalitis in patient with systemic lupus, India. Emerg Infect Dis 2006; 12(6): 984-986

293. Modica S, Miracco C, Cusi MG, Tordini G, Muzii VF, Iacoangeli F, Nocentini C, Ali IKM, Roy S, Cerase A, Zanelli G, De Luca A, Montagnani F. Non-granulomatous cerebellar infection by
Acanthamoeba spp. in an immunocompetent host. Infection 2018; 46(6): 885-889

294. Jung S, Schelper RL, Visvesvara GS, Chang HT. Balamuthia mandrillaris meningoencephalitis in an immunocompetent patient: an unusual clinical course and a favorable outcome. Arch Pathol Lab Med 2004; 128(4): 466-468

295. Harrison WT, Lecky B, Hulette CM. Fatal granulomatous amebic encephalitis in a heart transplant patient: clinical, radiographic, and autopsy findings. J Neuropathol Exp Neurol 2018; 77(11): 10011004

296. Parija SC, Dinoop K, Venugopal H. Management of granulomatous amebic encephalitis: laboratory diagnosis and treatment. Trop Parasitol 2015; 5(1): 23-28

297. Williams JE. Diagnostic medical parasitology. Parasitol Today 1998; 14(3): 125-126

298. Kang AY, Park AY, Shin HJ, Khan NA, Maciver SK, Jung SY. Production of a monoclonal antibody against a mannose-binding protein of Acanthamoeba culbertsoni and its localization. Exp Parasitol 2018; 192: 19-24

299. Guarner J, Bartlett J, Shieh WJ, Paddock CD, Visvesvara GS, Zaki SR. Histopathologic spectrum and immunohistochemical diagnosis of amebic meningoencephalitis. Mod Pathol 2007; 20(12): $1230-1237$

300. Kiderlen AF, Radam E, Tata PS. Assessment of Balamuthia mandrillaris-specific serum antibody concentrations by flow cytometry. Parasitol Res 2009; 104(3): 663-670

301. Kiderlen AF, Radam E, Schuster FL, Adjogoua EV, Akoua-Koffi C, Leendertz FH. Balamuthia and Acanthamoeba-binding antibodies in West African human sera. Exp Parasitol 2010; 126(1): 28-32

302. Schuster FL. Cultivation of pathogenic and opportunistic freeliving amebas. Clin Microbiol Rev 2002; 15(3): 342-354

303. Kiderlen AF, Radam E, Lewin A. Detection of Balamuthia mandrillaris DNA by real-time PCR targeting the RNase P gene. BMC Microbiol 2008; 8(1): 210

304. Yagi S, Booton GC, Visvesvara GS, Schuster FL. Detection of Balamuthia mitochondrial 16S rRNA gene DNA in clinical specimens by PCR. J Clin Microbiol 2005; 43(7): 3192-3197

305. Gabriel S, Rasheed AK, Siddiqui R, Appaturi JN, Fen LB, Khan NA. Development of nanoparticle-assisted PCR assay in the rapid detection of brain-eating amoebae. Parasitol Res 2018; 117(6): 1801-1811

306. Norgan AP, Sloan LM, Pritt BS. Detection of Naegleria fowleri, Acanthamoeba spp, and Balamuthia mandrillaris in formalinfixed, paraffin-embedded tissues by real-time multiplex polymerase chain reaction. Am J Clin Pathol 2019; 152(6): 799-807

307. Wilson MR, Shanbhag NM, Reid MJ, Singhal NS, Gelfand JM, Sample HA, Benkli B, O’Donovan BD, Ali IK, Keating MK, Dunnebacke TH, Wood MD, Bollen A, DeRisi JL. Diagnosing Balamuthia mandrillaris encephalitis with metagenomic deep sequencing. Ann Neurol 2015; 78(5): 722-730

308. Silva-Vergara ML, Da Cunha Colombo ER, De Figueiredo Vissotto E, Silva AC, Chica JE, Etchebehere RM, Adad SJ. Disseminated Balamuthia mandrillaris amoeba infection in an AIDS patient from Brazil. Am J Trop Med Hyg 2007; 77(6): 10961098

309. Silva RA, Araújo SA, Avellar IF, Pittella JE, Oliveira JT, Christo 
PP. Granulomatous amoebic meningoencephalitis in an immunocompetent patient. Arch Neurol 2010; 67(12): 1516-1520

310. Diaz JH. The public health threat from Balamuthia mandrillaris in the southern United States. J La State Med Soc 2011; 163(4): 197204

311. Krasaelap A, Prechawit S, Chansaenroj J, Punyahotra P, Puthanakit T, Chomtho K, Shuangshoti S, Amornfa J, Poovorawan Y. Fatal Balamuthia amebic encephalitis in a healthy child: a case report with review of survival cases. Korean J Parasitol 2013; 51(3): 335-341

312. Galarza M, Cuccia V, Sosa FP, Monges JA. Pediatric granulomatous cerebral amebiasis: a delayed diagnosis. Pediatr Neurol 2002; 26(2): 153-156

313. Pindyck TN, Dvorscak LE, Hart BL, Palestine MD, Gallant JE, Allen SE, SantaCruz KS. Fatal granulomatous amebic encephalitis due to Balamuthia mandrillaris in New Mexico: a case report. Open Forum Infect Dis 2014; 1(2): ofu062

314. Retana-Moreira L, Abrahams-Sandí E, Cabello-Vílchez AM, Reyes-Batlle M, Valladares B, Martínez-Carretero E, Piñero JE, Lorenzo-Morales J. Isolation and molecular characterization of Acanthamoeba and Balamuthia mandrillaris from combination shower units in Costa Rica. Parasitol Res 2014; 113(11): 41174122

315. Gabriel S, Khan NA, Siddiqui R. Occurrence of free-living amoebae (Acanthamoeba, Balamuthia, Naegleria) in water samples in Peninsular Malaysia. J Water Health 2019; 17(1): $160-171$

316. Mbaeyi C, Hlth CG. Notes From the Field: transplant-transmitted Balamuthia mandrillaris-Arizona, 2010 (Reprinted from MMWR, vol 59, pg 1182, 2010). JAMA 2011; 305(3): 249

317. DaSilvaNo author listed. Balamuthia mandrillaris transmitted through organ transplantation-Mississippi, 2009. Am J Transplant 2011; 11(1): 173-176

318. Schuster FL, Glaser C, Honarmand S, Maguire JH, Visvesvara GS. Balamuthia amebic encephalitis risk, Hispanic Americans. Emerg Infect Dis 2004; 10(8): 1510-1512

319. Schuster FL, Guglielmo BJ, Visvesvara GS. In-vitro activity of miltefosine and voriconazole on clinical isolates of free-living amebas: Balamuthia mandrillaris, Acanthamoeba spp., and Naegleria fowleri. J Eukaryot Microbiol 2006; 53(2): 121-126

320. Doyle JS, Campbell E, Fuller A, Spelman DW, Cameron R, Malham G, Gin D, Lewin SR. Balamuthia mandrillaris brain abscess successfully treated with complete surgical excision and prolonged combination antimicrobial therapy. J Neurosurg 2011; 114(2): 458-462

321. Siddiqui R, Aqeel Y, Khan NA. Killing the dead: chemotherapeutic strategies against free-living cyst-forming protists (Acanthamoeba sp. and Balamuthia mandrillaris). J Eukaryot Microbiol 2013; 60(3): 291-297

322. Marciano-Cabral F, Cabral G. Acanthamoeba spp. as agents of disease in humans. Clin Microbiol Rev 2003; 16(2): 273-307

323. Tunkel AR, Glaser CA, Bloch KC, Sejvar JJ, Marra CM, Roos KL, Hartman BJ, Kaplan SL, Scheld WM, Whitley RJ; Infectious Diseases Society of America. The management of encephalitis: clinical practice guidelines by the Infectious Diseases Society of America. Clin Infect Dis 2008; 47(3): 303-327

324. Cary LC, Maul E, Potter C, Wong P, Nelson PT, Given C 2nd, Robertson W Jr. Balamuthia mandrillaris meningoencephalitis: survival of a pediatric patient. Pediatrics 2010; 125(3): e699-e703

325. Orozco L, Hanigan W, Khan M, Fratkin J, Lee M. Neurosurgical intervention in the diagnosis and treatment of Balamuthia mandrillaris encephalitis. J Neurosurg 2011; 115(3): 636-640

326. Laurie MT, White CV, Retallack H, Wu W, Moser MS, Sakanari JA, Ang K, Wilson C, Arkin MR, DeRisi JL. Functional assessment of 2,177 U.S. and international drugs identifies the quinoline nitroxoline as a potent amoebicidal agent against the pathogen Balamuthia mandrillaris. MBio 2018; 9(5): e02051-18

327. Deetz TR, Sawyer MH, Billman G, Schuster FL, Visvesvara GS. Successful treatment of Balamuthia amoebic encephalitis: presentation of 2 cases. Clin Infect Dis 2003; 37(10): 1304-1312

328. Gondim BLC, da Silva Catarino J, de Sousa MAD, de Oliveira Silva M, Lemes MR, de Carvalho-Costa TM, de Lima Nascimento TR, Machado JR, Rodrigues V, Oliveira CJF, Cançado Castellano LR, da Silva MV. Nanoparticle-mediated drug delivery: bloodbrain barrier as the main obstacle to treating infectious diseases in CNS. Curr Pharm Des 2019; 25(37): 3983-3996 